OECDpublishing

\title{
MULTINATIONAL ENTERPRISES \\ IN DOMESTIC VALUE CHAINS
}

OECD SCIENCE, TECHNOLOGY AND INDUSTRY POLICY PAPERS

March 2019 No. 63 
This paper was approved and declassified by written procedure by the Committee on Industry, Innovation and Entrepreneurship (CIIE) on 6 December 2018 and prepared for publication by the OECD Secretariat.

Note to Delegations:

This document is also available on O.N.E under the reference code:

DSTI/CIIE(2018)10/FINAL

This document, as well as any data and any map included herein, are without prejudice to the status of or sovereignty over any territory, to the delimitation of international frontiers and boundaries and to the name of any territory, city or area.

(C) OECD (2019)

You can copy, download or print OECD content for your own use, and you can include excerpts from OECD publications, databases and multimedia products in your own documents, presentations, blogs, websites and teaching materials, provided that suitable acknowledgment of OECD as source and copyright owner is given. All requests for commercial use and translation rights should be submitted to rights@oecd.org. 


\section{Table of contents}

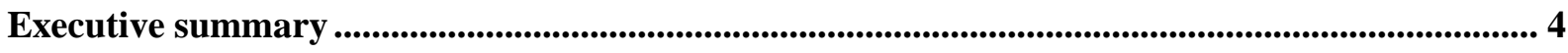

Multinational enterprises in domestic value chains ...................................................................6

1. Introduction - policy rationale........................................................................................................................... 6

2. Direct effects of MNE affiliates in host countries .............................................................. 10

3. Indirect effects of MNE affiliates: some first evidence on MNEs involvement in domestic value chains ............................................................................................................................................................... 12

4. A more systematic look at indirect effects through input-output multipliers.............................. 23

5. Policy discussion and implications ............................................................................................ 31

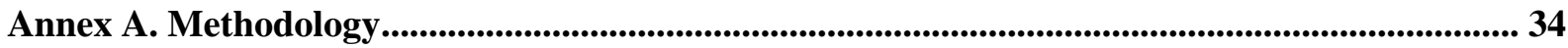

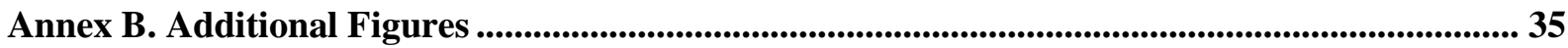

Figures

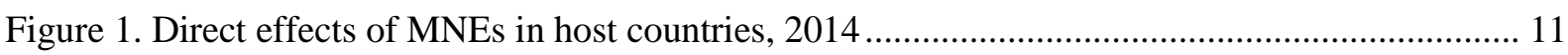

Figure 2. Sourcing structure of foreign affiliates and domestic firms, world, total economy, 2014 .... 13

Figure 3. Sourcing structure of foreign affiliates, OECD and BRIICS, total economy, 2014 ............. 15

Figure 4. Sourcing structure of foreign affiliates, individual countries, total economy, 2014 ............. 16

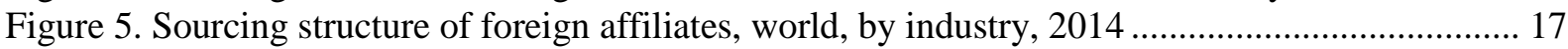

Figure 6. Output use of foreign affiliates and domestic firms, world, total economy, 2014 ............... 19

Figure 7. Output use of foreign affiliates, OECD and BRIICS countries, total economy 2014 ........... 20

Figure 8. Output use of foreign affiliates, individual countries, total economy 2014 .......................... 21

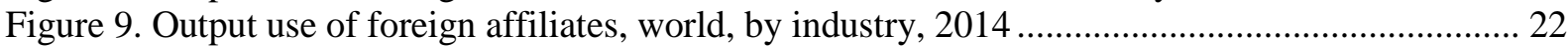

Figure 10. Backward output multiplier of foreign affiliates, world average, total economy ............... 24

Figure 11. Backward output multiplier of foreign affiliates, manufacturing and services, $2014 \ldots \ldots \ldots .25$

Figure 12. Forward output multiplier of foreign affiliates, world average, total economy, 2014 ........ 27

Figure 13. Percentage GDP change, "A world without foreign affiliates", individual industries ......... 29

Figure 14. Percentage GDP change, "A world without foreign affiliates", individual countries........... 30

\section{Boxes}

Box 1. Spillovers from MNEs

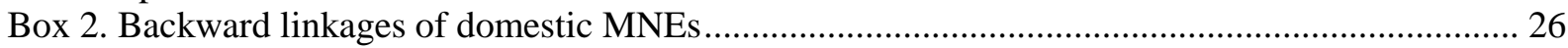




\section{Executive summary}

The activities of multinational enterprises (MNEs) have traditionally attracted a lot of policy attention since MNEs contribute to growth and employment by creating new jobs, realise new investments and develop new technologies. The evidence base on MNE activities and their benefits - direct and indirect - across economies is surprisingly much more limited. This paper analyses the domestic linkages of MNE affiliates in host economies in order to get better insights in the role MNEs play across countries. Direct effects of MNEs in terms of output, value added, international trade and jobs are discussed, as well as indirect effects since MNE affiliates generate up- and downstream effects in domestic value chains. The empirical evidence developed in this paper builds on the OECD Analytical AMNE database covering 44 countries (including Rest of the World) and 43 industries for the years 2000-14.

A first result is that MNE affiliates in host countries generate important direct effects in terms of output, value added, international trade and jobs. Domestic MNEs - i.e. headquarters and domestic plants in the home country of the MNE - have similar if not larger direct effects. For example, the new evidence indicates that MNEs account roughly for one-half of international trade, one-third of output and GDP and one-fourth of employment in the global economy. Further on, for each job abroad in their foreign affiliates, MNEs have more than two jobs at home.

But MNE affiliates also generate important indirect effects dependent on how strongly integrated they are into domestic economies. On average at the global level, every 1 USD of extra sales by foreign affiliates generates another USD 0.62 for the domestic economies in which they are located. Differences exist across countries and industries, but the assertion that foreign affiliates operate in an isolated manner in host countries and source all intermediate goods and services from within their MNE network does not seem to be supported by the data. Instead, foreign affiliates contract and co-operate increasingly with domestic suppliers, including SMEs, in their operations. In addition, the results demonstrate the importance of foreign affiliates in domestic value chains, not only as customers for locally produced inputs, tradeable as well as non-tradeable, but also as suppliers of final and intermediate products sold and used within the domestic economy.

Foreign affiliates are important gateways to international markets and connect the domestic value chain with global value chains. The domestic part of the value chain is often as important as its foreign part since MNEs frequently rely on SMEs to become global firms and expand internationally. Competitive national economies harbour domestic firms (which are to a large extent SMEs), domestic MNEs as well as foreign affiliates, reflecting economies' attractiveness for doing business locally. Policies need thus to be inclusive for the different types of companies.

The evidence suggests that it may be counterproductive to create targeted incentives for some companies to participate in GVCs - e.g. on the presumption that internationally active companies provide important benefits to the host economy - while largely ignoring domestic companies involved in the value chain. It is therefore important to create a conducive domestic policy environment for firms of all size and engaged in all types of operations (international or domestic). 
Linkages between foreign affiliates and domestic firms rarely happen on their own, hence the possible need for policy action in close co-operation with industry associations. SMEs account for a large part of domestic suppliers, and are often constrained by resources (and time) while new MNE affiliates may not be fully informed about the local business environment, information building and sharing on possible and future supply opportunities may be helpful.

In addition, the creation of domestic linkages is dependent on the capabilities of domestic suppliers. In order to respond to the production needs of MNEs, the absorptive capacities of domestic firms will need to be reinforced. Government support to education, training, formation, etc. will help domestic companies to connect and co-operate more intensively with MNE affiliates.

The importance of domestic linkages between MNE affiliates and domestic suppliers and their (in)direct effects on host economies is often used as an argument in favour of policy intervention. But policies (e.g. local content requirements) imposed by governments that require firms to use domestically manufactured goods or domestically supplied services are counter-productive as they have been shown to undermine long-term industrial competitiveness. Stronger domestic linkages are created when foreign firms find competitive partners in the domestic economy. 


\section{Multinational enterprises in domestic value chains}

\section{Introduction - policy rationale}

The activities of multinational enterprises (MNEs) have traditionally attracted a lot of policy attention. Governments in OECD as well as emerging economies are keen to attract international investments because MNEs promote growth and employment by creating new jobs, realise new investments and bring in new technologies. Not uncommonly, direct support (be it fiscal, financial, the provision of specific infrastructure, etc.) is offered to attract new international investments with evidence showing that especially large companies are able to negotiate incentive packages (OECD, 2011).

There is however a large debate whether the use of public money for attracting MNEs is economically justifiable. The argument in favour of government intervention is largely based on the direct (i.e. the value added, employment, etc. that they create directly in home and host countries) and indirectly (i.e. the value added, employment, etc. that they generate because of their linkages with domestic firms). Furthermore, MNEs are also often favoured by policy makers as they are deemed to allow host economies to integrate and upgrade in GVCs (much) faster than domestic firms could do. A last category of impacts MNEs may generate is related to the existence of externalities, as unintended benefits might spill over from MNEs to local firms and result in productivity growth for the host economy (Caves, 1996).

While location-based incentives may play some role especially in the final stages of the MNEs' decision-making process, they also create scope for rent-seeking behaviour. Critics argue that government support merely reflects officials' private interests, and that the costs to the host economy are often larger than the benefits (Greenstone and Moretti, 2004). Another argument against government intervention to attract foreign MNEs, is that spillovers may also arise from domestic firms, particularly indigenous MNEs. If international investors do not differ fundamentally from local investors, selective government incentives for foreign direct investment (FDI) may distort competition with local firms (Blomström and Kokko, 2003).

Despite the extensive policy discussion around MNEs, the evidence base on MNE activities and their benefits across economies is - surprisingly - much more limited. Empirical evidence on MNEs is not widely available and largely incomplete, with data on MNE activities only available for a subset of OECD countries. As a consequence, the (policy) discussion on the value that MNEs contribute to national economies - directly as well as indirectly - often remains rather cursory. This paper aims to analyse the domestic linkages of MNE affiliates in host economies in order to get better insights in the role MNEs play across countries. Direct effects of MNEs in terms of output, value added, international trade and jobs are discussed, as well as indirect effects since MNE affiliates are expected to generate up- and downstream effects in domestic value chains.

The empirical evidence developed in this paper builds on the OECD Analytical AMNE database covering 44 countries (including Rest of the World) and 43 industries for the years 
2000-2014 (Cadestin et al., 2018a). Complete information is available on the activities of foreign affiliates in host countries and for more recent years also on the activities of MNEs headquarters (and their domestic affiliates) in home countries. This analytical AMNE database itself is based on the official MNE statistics collected by National Statistical Offices, complemented with estimates for missing information using different statistical techniques and additional information. This new database has been linked with the WIOD Inter-Country Input-Output tables, providing important insights on the (voluntary) links and interrelationships between MNEs and the domestic sector in host/home countries (Cadestin et al., 2018b).

In discussing the role of MNEs in domestic value chains and their domestic linkages, the paper tries to provide answers to policy questions such as "To what extent are MNEs integrated in the domestic economy?", "Do MNE affiliates source from domestic SMEs or do they rather remain isolated pockets of production?", "What is the role of MNEs in domestic value chains?", "What is the dependence of the domestic sector on foreign affiliates and vice versa?". The paper also presents some evidence on the possible effects that could happen if foreign affiliates decide to leave host economies.

The paper does not, however, attempt to assess possible spillover effects of MNEs per se. These externalities - arising from (involuntary) technology transfers and knowledge flows from MNEs - have been the subject of a large but inconclusive literature. The vast number of studies on possible spillovers by MNEs has overall provided mixed results in terms of the magnitude, direction and even existence of spillovers (Smeets, 2008). In order to explain the ambiguous results, the literature has increasingly discussed different conditions for spillover effects to materialise, including the size and structure of linkages between MNEs and the domestic sector (see Box 1). Thus, while not presenting a "traditional" analysis on MNE spillovers, this paper ought to contribute to the spillover literature but in a different way (i.e. by measuring indirect effects that can be a source of spilllovers). 


\section{Box 1. Spillovers from MNEs}

The basic premise underlying the existence of spillovers from MNEs is that foreign-invested firms are technologically superior and unintended benefits might spill over from MNEs to local firms resulting in productivity growth for the host economy (Caves, 1996). By encouraging MNEs to establish local affiliates, host countries hope to generate technology transfers to local firms since foreign direct investment (FDI) is believed to be one of the most important channels through which technology is transferred across countries (OECD, 2008). The spillover literature is however ambiguous with large numbers of papers finding evidence of positive spillovers, others finding insignificant results, while still other papers (especially analysing emerging economies) reporting significant negative spillovers. Meta-analyses of different studies point to methodological as well as measurement issues among others in explaining the contradictory results between studies (Blomström and Kokko, 1998, Görg and Strobl, 2001; Lipsey and Sjöholm, 2005; Havrãnek and Irsova; 2011; to name a few).

Because externalities are hard to measure ${ }^{1}$, the literature has traditionally tried to analyse the correlation between the (international) investment on the one side and the performance (productivity, sales, $\mathrm{R} \& \mathrm{D}$, etc.) of the likely beneficiaries in the host country. Over the years, more elaborated models have been applied to capture conditions that shape MNE spillovers by developing a metric for measuring the "closeness" of the likely recipients based on technological similarity, geographic proximity, or economic relationships (e.g. such as vendors and their customers).

First, accounting more explicitly for the different channels of spillovers helps to explain (some of) the differences between studies. For example, studies focusing on worker mobility as a first spillover - i.e. highly skilled staff moving from MNEs to domestic firms may take with them knowledge which may be usefully applied in the domestic firm - find overall positive effects. Likewise, demonstration effects - when domestic firms learn superior production technologies from MNEs through imitation, reverse engineering, etc. - seem to receive more empirical support when explicitly modelled for. Last but not least, vertical linkages within value chains seem to be better in facilitating spillovers than horizontal relationships. A "competition" effect from MNEs may force domestic rivals to up-date production technologies and techniques to become more productive but also attract demand away from domestic firms. It is clear that this competition effect is more prominent within industries and horizontal linkages.

Second, in addition to spillover channels, a number of mediating factors have been studied that also seem to explain the ambiguity of empirical studies (Smeets, 2008). Spillovers from MNEs to the host economy do not occur automatically and might not materialise in reality. Absorptive capacity has been demonstrated to have an important effect on spillovers, indicating that domestic firms need to possess a minimum of knowledge in order to capture and absorb spillovers. Also spatial proximity seem to affect the incidence and size of 
spillovers as being geographically close to the knowledge source is important for these externalities to arise.

Third, another stream of research has focused on heterogeneity among MNEs in analysing spillovers. Studies have analysed among others the type of ownership (majority, minority, joint-venture, etc.), the nationality of the parent company and the motives for international investment. Because of differences in research set-up and methodologies, this research has not always obtained equivocal results.

It is clear that the (theoretical as well empirical) research has not fully disentangled the different factors that affect the existence and magnitude of spillover effects of MNEs. Given so many factors at the country, industry, regional and firm-level, it may be however impossible to derive universal conclusions (Smeets, 2008). Nevertheless, the policy discussion will benefit from better insights as the argument for government support to attract MNEs is largely based on the existence of spillovers. 


\section{Direct effects of MNE affiliates in host countries}

MNE affiliates occupy an important role in host countries as demonstrated by their direct effects across a number of indicators (Figure 1). For example, foreign affiliates are estimated to produce about $12 \%$ of global output which corresponded to USD 19.5 trillion (figures for 2014) $)^{2}$. As a comparison, MNE headquarters and domestic plants - i.e. domestic MNEs - made up another $21 \%$ of global output. Taken together, this means that about one-third of global output is produced by MNEs, illustrating the importance of MNEs and their networks in today's global economy. Nevertheless, this figure is much lower than what sometimes has been put forward based on partial information.

Foreign affiliates also accounted for about 10\% of world GDP in 2014, i.e. USD 7.7 trillion of value added created by them in host countries. More than 60 per cent of the global output by foreign affiliates consists of intermediate goods/services (see also below) - to some extent sourced internationally from within their MNE network - which explains why their share in GDP is smaller than their output share. Indeed, the value of imported intermediates are counted only once as a contribution to the original country's GDP, while it is included in the gross output statistics multiple times in different countries. For instance, when a foreign affiliate sources inputs from its headquarters to be incorporated into a final product, the value of the inputs is counted twice: in the output of the home country and of the host country of the affiliate, while only once in the GDP of the home country.

MNE affiliates are found to be relatively more important in exports and imports, demonstrating the large trading activities of this group of firms. Foreign affiliates were in 2014 responsible for respectively $31 \%$ and $28 \%$ of global exports and imports. These shares were higher than those of MNE headquarters ${ }^{3}$ (24\% and $21 \%$ respectively), but important differences exist across countries as available data for individual countries demonstrate. For example, MNEs accounted for more than $80 \%$ of exports by both France and Hungary, but mainly because of foreign affiliates in the case of Hungary while domestic MNEs play a much more important role in France.

Since MNEs are typically characterised by higher labour productivity, their overall share in global employment is relatively lower: about 23\% in 2014. MNEs thus still employ more personnel in their home countries than abroad: for each job found abroad, more than two jobs exist at home. MNE affiliates in host countries accounted in 2014 for about $7 \%$ of total employment, which corresponded to 125 million jobs. 
Figure 1. Direct effects of MNEs in host countries, 2014

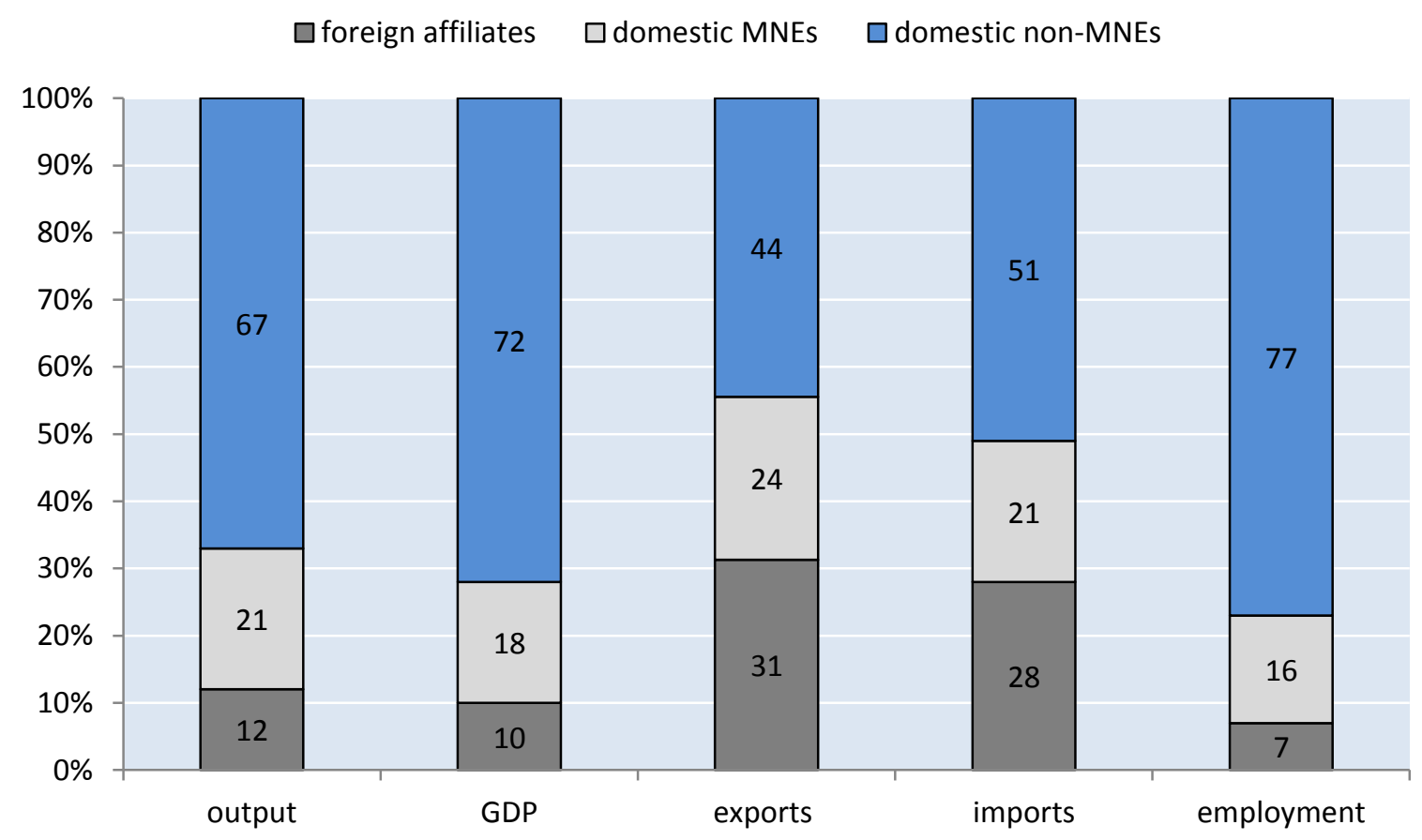

Source: Calculations based on the OECD Analytical AMNE database. 


\section{Indirect effects of MNE affiliates: some first evidence on MNEs involvement in domestic value chains}

\subsection{Backward linkages}

A first way to discuss domestic linkages and MNEs' involvement in domestic value chains is to analyse in more detail the sourcing structure of MNE affiliates in host countries. One type of domestic linkage arises because foreign affiliates buy inputs as customers from within the domestic economy, including from domestic SMEs. While policy makers expect that the establishment of foreign MNEs will benefit domestic suppliers, (anecdotal) evidence - particularly in emerging economies where domestic suppliers do not always possess the necessary capabilities - has suggested that foreign affiliates sometimes produce in a rather isolated manner in host economies and import the majority of their inputs from abroad, often from within their MNE networks.

The results of our analysis overall show that - compared to the average domestic firm foreign affiliates buy more intermediates than domestic companies (consequently, have a lower value-added/output ratio) and source these intermediates relatively more from abroad (hence incorporate larger foreign value added in their output) (Figure 2). On average, bought-in intermediates accounted for $61 \%$ of the output (with value added accounting for the other $39 \%^{4}$ ) by foreign affiliates in 2014. More than two-thirds (or $42 \%$ in terms of production) of these intermediates were sourced locally, i.e. from domestic value chains, representing a value of USD 8.1 trillion globally in 2014. 
Figure 2. Sourcing structure of foreign affiliates and domestic firms, world, total economy, 2014

Foreign affiliates

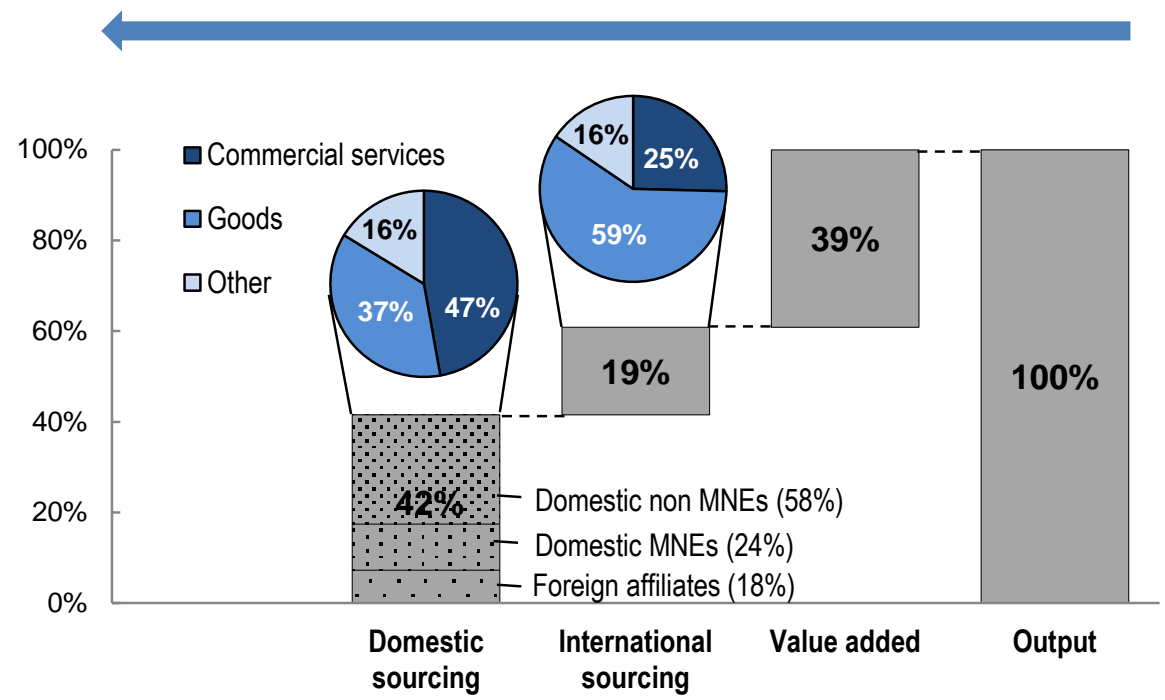

Domestic firms

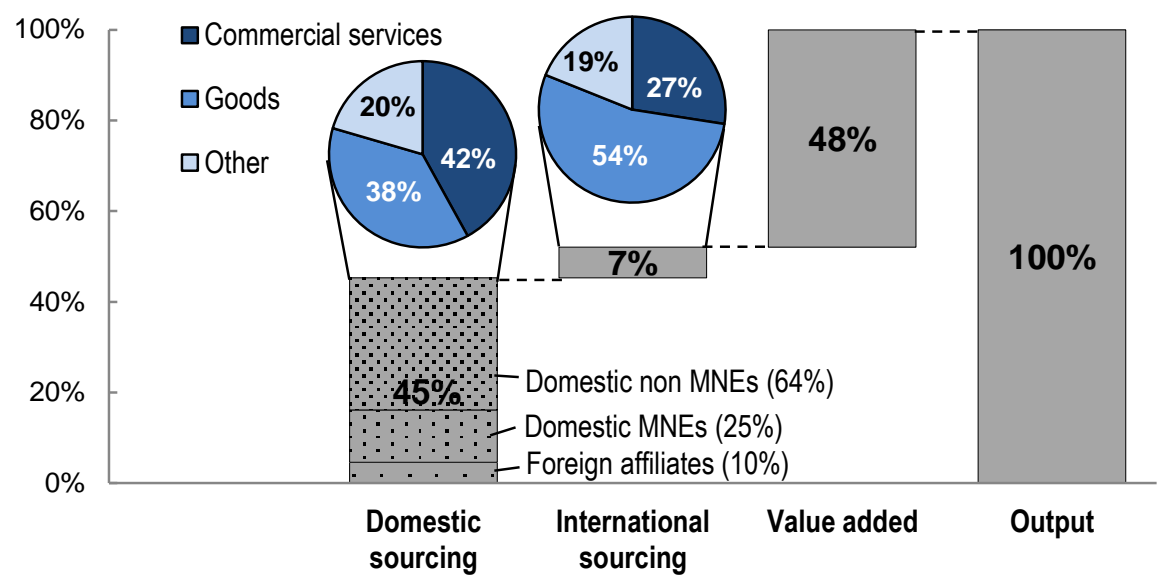

Source: Calculations based on the OECD Analytical AMNE database.

The domestic sourcing consisted of $37 \%$ of manufactured goods and $47 \%$ of commercial services in 2014. Domestic sourcing of services seems to have decreased over time which may reflect the growing international provision of services (e.g. via the Internet). On the other hand, services are still significantly more sourced domestically: only $25 \%$ of international sourcing by foreign affiliates concerned services in 2014 . The results indicate that foreign affiliates but also domestic firms use international sourcing especially for the acquisition of goods. 
The domestic sourcing of intermediates by foreign affiliates largely benefits domestic firms, of which the majority are SMEs $5.58 \%$ of the domestic intermediate consumption by foreign affiliates was supplied by domestic non-MNEs in 2014. These figures demonstrate the importance of domestic SMEs for the operation - also at an international level - of MNE affiliates. Foreign affiliates are found to source intermediates also from domestic MNEs (24\% in 2014) and other foreign affiliates in the host country (18\%) which shows that important sourcing linkages among foreign affiliates exist in host countries. The automotive industry serves as a good example since car assemblers often maintain their usual business partners - particularly first-tier suppliers - when locating abroad because of the intensive collaboration (also on design, $R \& D$, etc.) between them.

Not surprisingly, the sourcing structure of foreign affiliates is significantly different from that of the average domestic firm. Domestic firms create relatively more value added per unit production (48\% versus 39\%) and source their intermediates more from within the domestic (host) economy (87\% versus 68\%). Furthermore, their sourcing from foreign affiliates in the domestic economy is substantially lower.

Because of the growing importance of GVCs, the sourcing structure of foreign affiliates in domestic value chains has changed over time. Production by foreign affiliates in 2000 consisted of $43 \%$ value added (created by foreign affiliates themselves in host countries) and $57 \%$ intermediates, indicating that the value added/production ratio has decreased since then. Since 2000 international sourcing has increased slightly more than domestic sourcing, further underlining the growing international fragmentation of production. Domestic sourcing by foreign affiliates has over the years shifted slightly towards goods although the changes are small.

A number of differences emerge between OECD and BRIICS countries ${ }^{6}$ when analysing the sourcing structure of foreign affiliates (Figure 3). In BRIICS economies, foreign affiliates buy in relatively more intermediates (hence, a lower value added/production ration). The sourcing of intermediates however is more oriented towards the domestic sector with "only" $15 \%$ of intermediates (or $11 \%$ of production) sourced from abroad in 2014. Domestic SMEs are the main suppliers to foreign affiliates (61\%), followed by domestic MNEs and other foreign affiliates. Foreign affiliates located in OECD countries source relatively less from external suppliers (58\% versus $70 \%)$ but relatively more from abroad (20\% versus 11\%). Domestic non-MNEs including SMEs are also the largest beneficiaries of the sourcing by foreign affiliates.

Different reasons may explain this somewhat surprising observation that domestic sourcing in emerging economies like the BRIICS is more important. On the one hand, some evidence indeed suggests that domestic suppliers in emerging economies have overall lower capabilities, hence the need for foreign affiliates to look for suppliers abroad. On the other hand, however, transport, logistics, telecommunications costs are typically higher in emerging countries due to poor services regulations. Furthermore, markets are generally more closed in these countries so that often domestic suppliers are the only available choice. Based on the data, it would seem that the latter two effects dominate the first effect. 
Figure 3. Sourcing structure of foreign affiliates, OECD and BRIICS, total economy, 2014

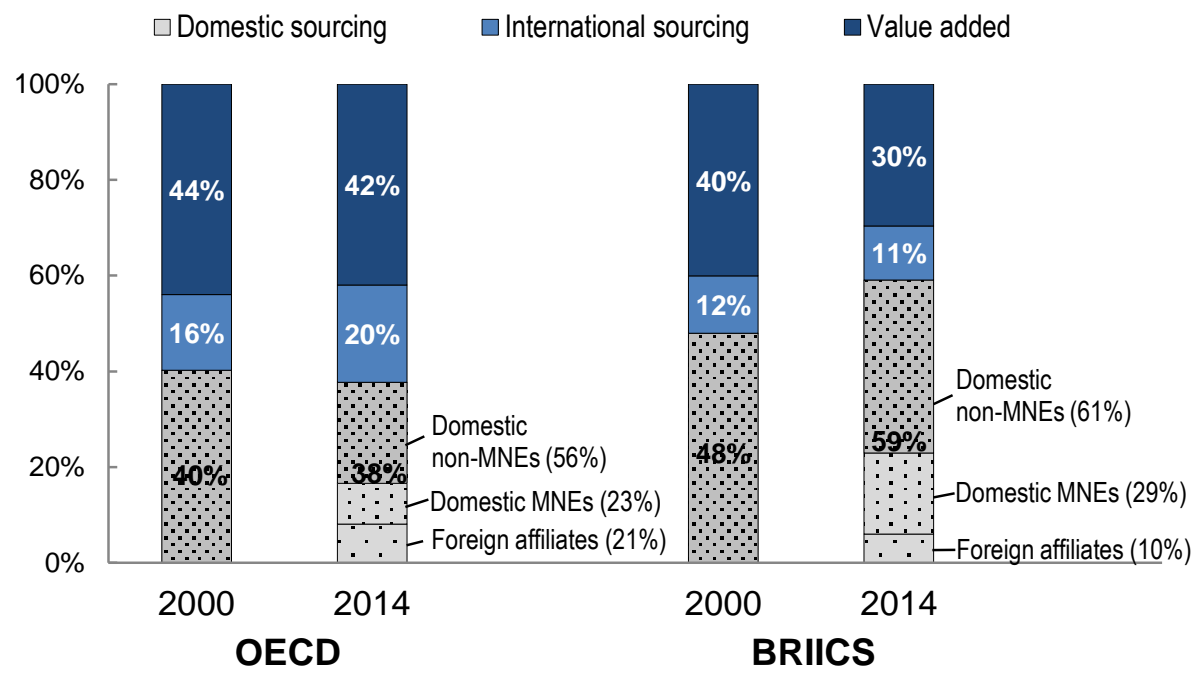

Source: Calculations based on the OECD Analytical AMNE database.

Figure 4 presenting the results at the individual country level shows a large heterogeneity across countries. Important domestic linkages through local sourcing by foreign affiliates exist in France, Italy, the United States and Japan. The size of the country seems to matter as larger countries have typically a larger variety of domestic suppliers - a similar finding has emerged from the OECD TiVA database with larger economies typically displaying a smaller foreign value added of exports. In (smaller) countries like Belgium, Luxembourg and Ireland, foreign affiliates are found to source especially from abroad. Domestic SMEs are the most important domestic suppliers to foreign affiliates across all countries although interesting differences arise between countries. For example, the large domestic sourcing by foreign affiliates in France and the United States goes to domestic non-MNEs as well as domestic MNEs (reflecting the larger presence of incumbent MNEs in these countries), while in Italy domestic sourcing by foreign affiliates especially benefits domestic nonMNEs. A last interesting observation is that in Eastern European countries domestic sourcing from other foreign affiliates is observed to be overall more important. 
Figure 4. Sourcing structure of foreign affiliates, individual countries, total economy, 2014

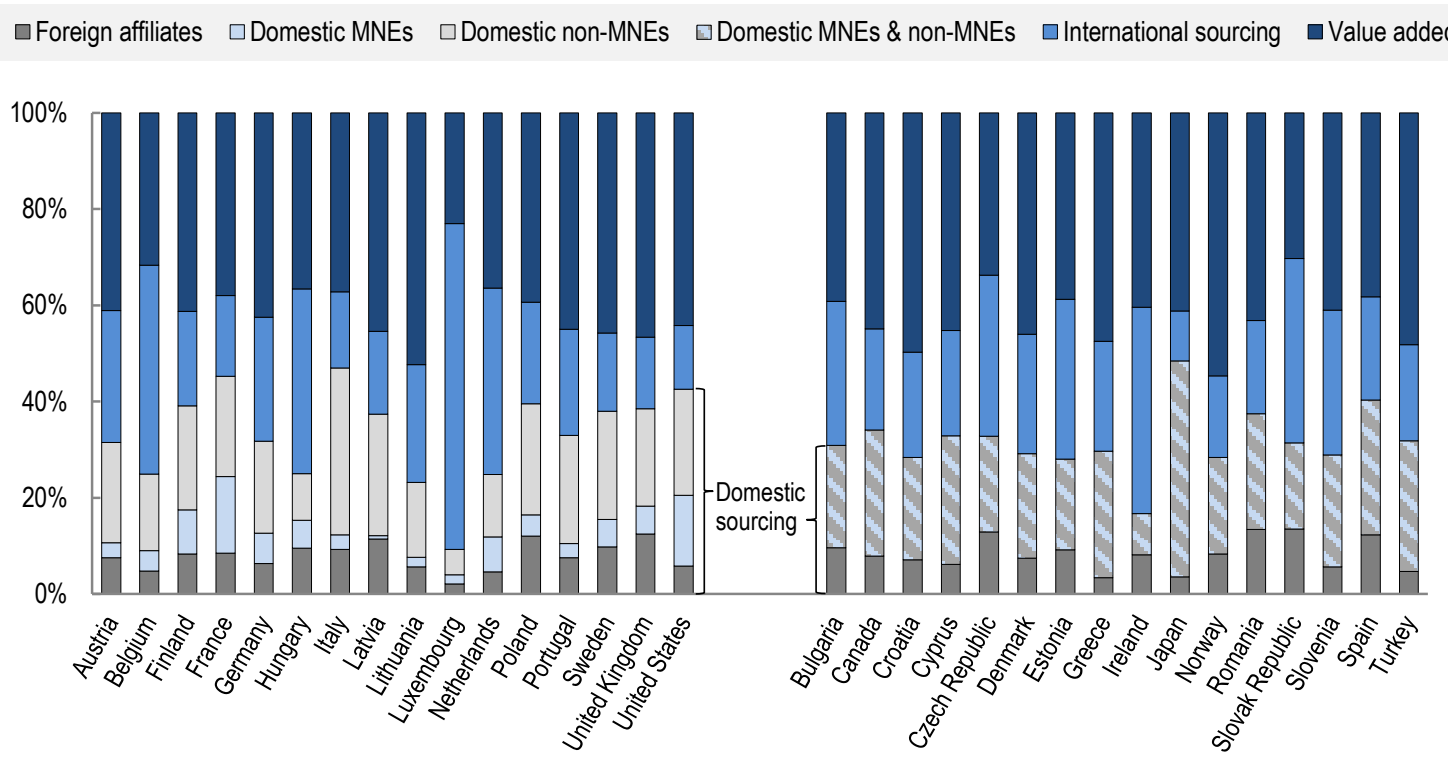

Note: Only countries are included for which official MNE data are available. The first group of countries publishes data on foreign affiliates as well as domestic MNEs, hence results are presented for domestic sourcing from foreign affiliates, domestic MNEs and non-MNEs. The second group of countries publishes only data on foreign affiliates, hence results are presented for domestic sourcing from foreign affiliates and domestic companies (MNEs and non-MNEs together) ${ }^{7}$.

1. Note by Turkey:

The information in this document with reference to "Cyprus" relates to the southern part of the Island. There is no single authority representing both Turkish and Greek Cypriot people on the Island. Turkey recognises the Turkish Republic of Northern Cyprus (TRNC). Until a lasting and equitable solution is found within the context of the United Nations, Turkey shall preserve its position concerning the "Cyprus issue."

2. Note by all the European Union Member States of the OECD and the European Union:

The Republic of Cyprus is recognised by all members of the United Nations with the exception of Turkey. The information in this document relates to the area under the effective control of the Government of the Republic of Cyprus.

Source: Calculations based on the OECD Analytical AMNE database.

Figure 5 presents the sourcing structure of foreign affiliates in individual industries. Manufacturing industries are overall characterised by a lower value added/production ratio and higher international sourcing. In industries like "food and tobacco", "textiles and leather", "paper and printing" and "wood", foreign affiliates are found to source significantly locally from SMEs and other non-MNEs. It is related to the use of perishable inputs or bulky inputs that are more difficult to source internationally. There is also a trend among consumers to favour products made domestically in some of these industries. However, domestic non-MNEs also play a large role in the (domestic) sourcing by foreign affiliates in other industries including metal products, electrical and machinery. The transport industry is the industry where sourcing among foreign affiliates is the largest.

Compared to manufacturing industries, services industries are overall characterised by higher value added creation and lower international sourcing (which is most likely a reflection of the "local" character of services: close contact between producer and consumer, technical impossibility to transport services across (large) distances, etc.). The domestic linkages of foreign affiliates in services industries benefit especially domestic 
SMEs and non-MNEs. International sourcing is found to be important in "land transport", "air transport" and "computer and information services".

Figure 5. Sourcing structure of foreign affiliates, world, by industry, 2014

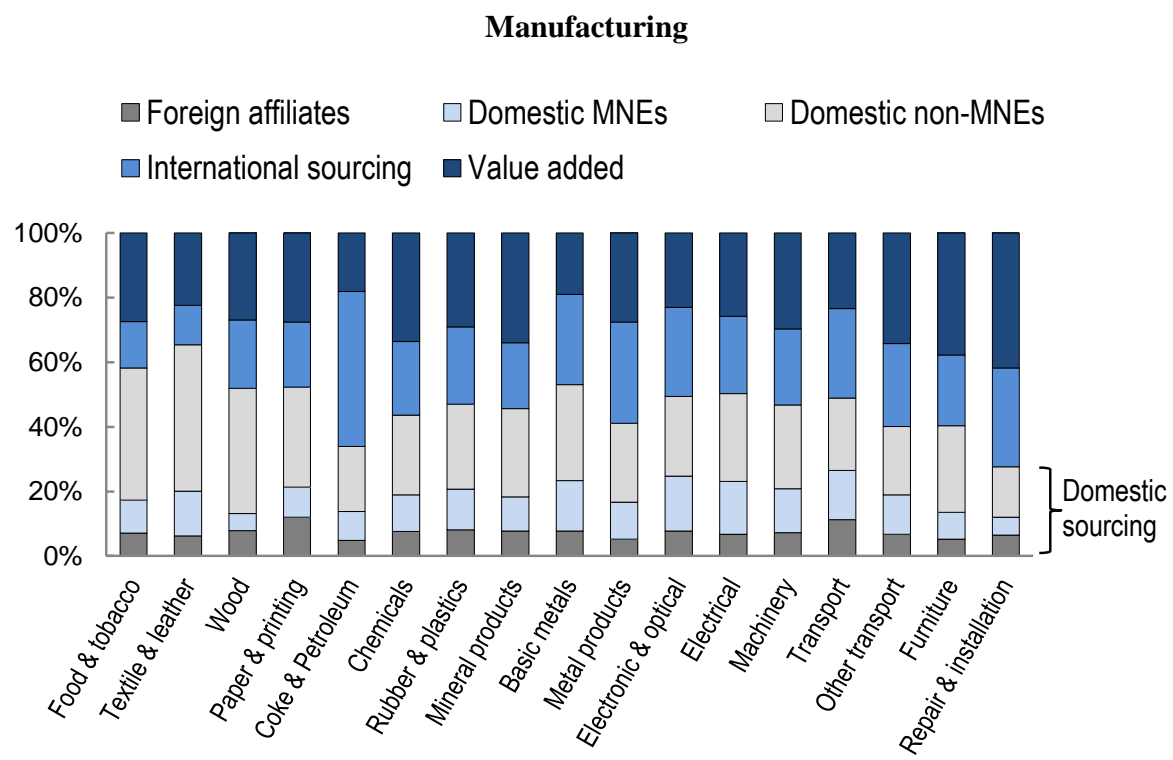

Services

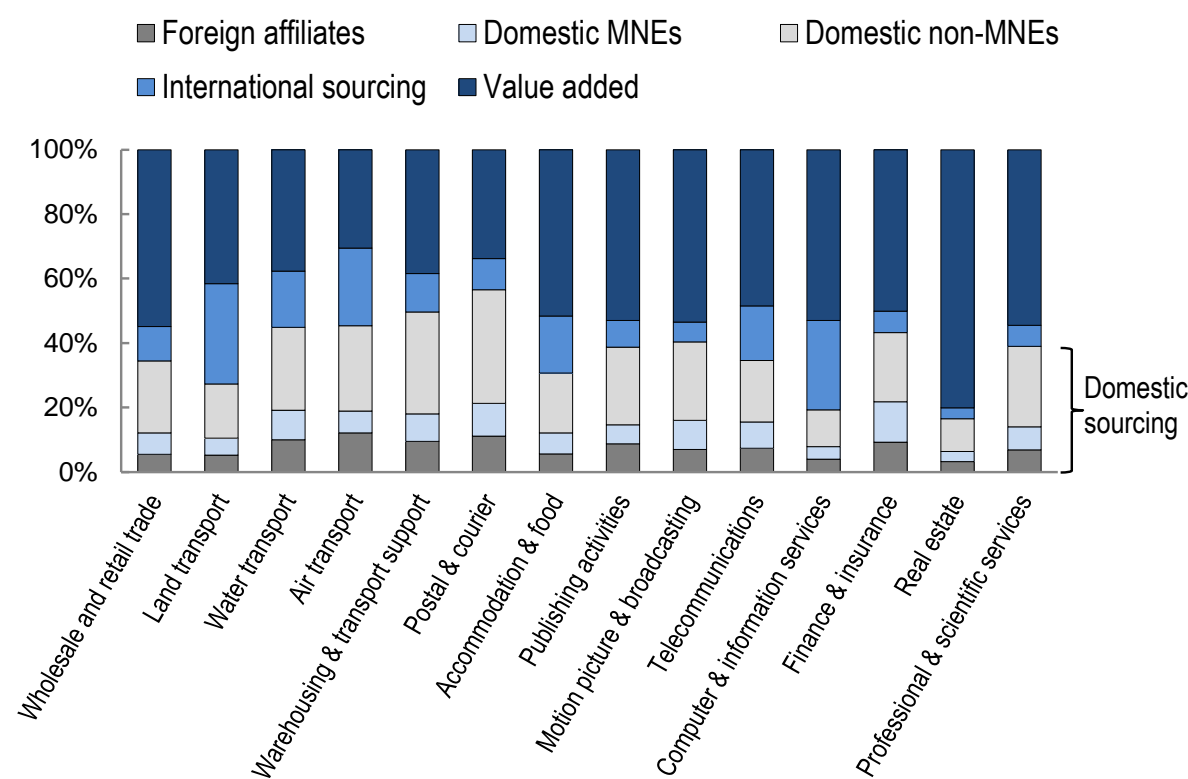

Source: Calculations based on the OECD Analytical AMNE database.

\subsection{Forward linkages}

Foreign affiliates operate not only as customers in host countries, but also as suppliers of intermediates (bought-in by other firms) and final products. A second way to discuss the 
integration of foreign affiliates in domestic value chains is to look forward in the value chain and analyse what the destination is of the output of MNE affiliates in host countries. For example, do foreign affiliates produce especially for the domestic market or rather for international markets? And by distinguishing between final and intermediate products, we can analyse how foreign affiliates' output becomes an input for domestic firms.

About two-thirds of the production by foreign affiliates (i.e. USD 13 billion in 2014) feeds (back) into domestic value chains: $26 \%$ of affiliates' production in 2014 was destined for the final domestic market while $41 \%$ was used locally as an input to other firms in the domestic economy (Figure 6). These shares have decreased somewhat since 2000 particularly the share for final domestic demand - reflecting the growing impact of GVCs on national economies. The domestic forward effects of the average domestic firm are - not surprisingly given the purely domestic activities of domestic SMEs - significantly larger: $90 \%$ of the average domestic firm "stays" in the domestic economy.

In addition to producing final products for the domestic markets, foreign affiliates produce intermediates for domestic companies in host economies to a considerable extent. More than one-third of foreign affiliates' production serves as an input in the production processes of domestic companies, particularly domestic non-MNEs and to a lesser extent domestic MNEs. 
Figure 6. Output use of foreign affiliates and domestic firms, world, total economy, 2014

Foreign affiliates

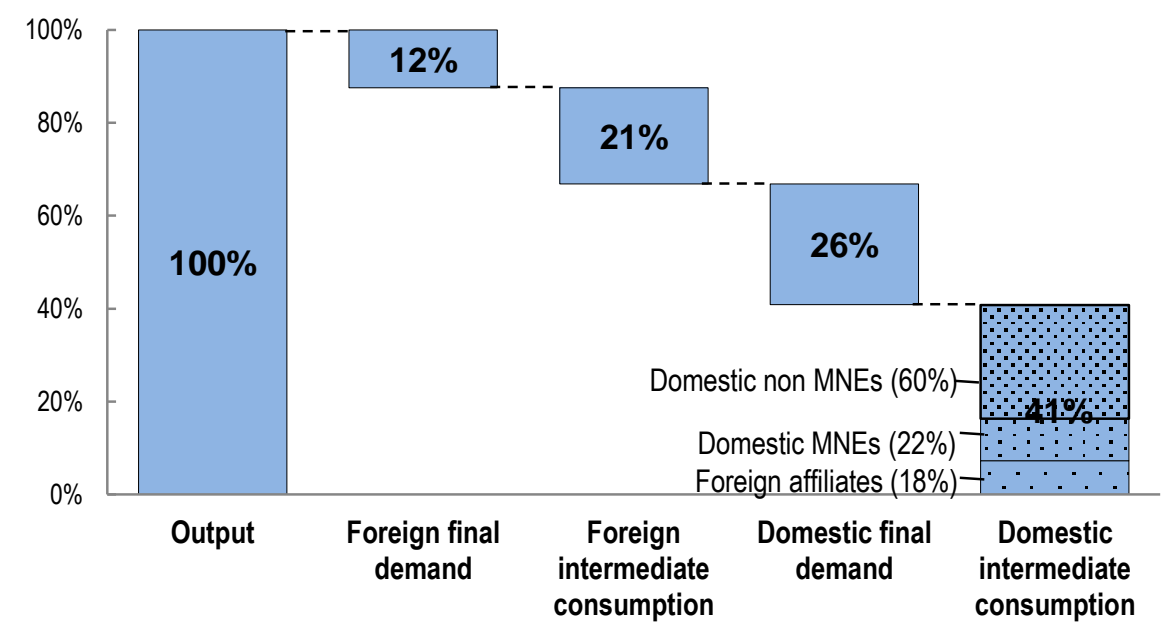

Domestic firms

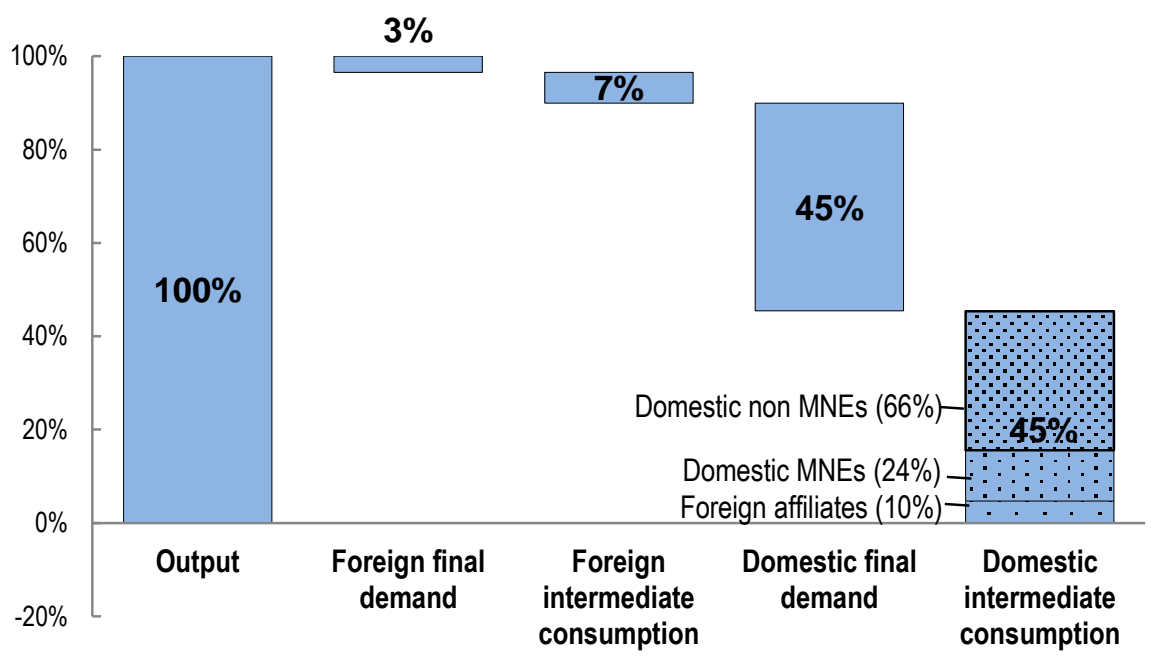

Source: Calculations based on the OECD Analytical AMNE database.

When comparing OECD and BRIICS economies, the results in Figure 7 show that production by foreign affiliates is relatively more destined for local markets in the BRIICS economies: $71 \%$ in BRIICS economies versus $65 \%$ in OECD countries. These shares have been falling since 2000 especially in emerging economies with a growing part of affiliates' output in these countries going to international markets. These results seem to confirm that 
the large and growing domestic markets in BRIICS countries are an important location factor for MNEs. At the same time, the results in Figure 7 also demonstrate the importance of these countries as centres of production (including assembly) in MNE networks. The output of foreign affiliates in OECD countries is more destined for final markets ( $40 \%$ final versus $60 \%$ intermediate), while the foreign affiliates' production in BRIICS countries concern relatively more intermediate products ( $35 \%$ final versus 65 intermediate).

Figure 7. Output use of foreign affiliates, OECD and BRIICS countries, total economy 2014

$\square$ Domestic intermediate consumption

- International intermediate consumption

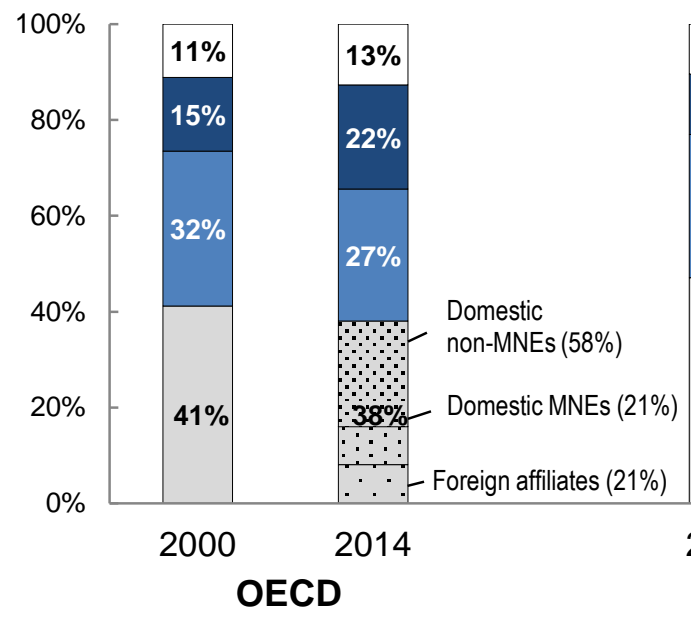

$\square$ Domestic final demand

$\square$ International final demand

Source: Calculations based on the OECD Analytical AMNE database.

Forward linkages of foreign affiliates show a large heterogeneity across individual countries (Figure 8). In countries like Belgium, Luxembourg, the Netherlands and Ireland, foreign affiliates are found to export the majority of their (final and intermediate) production to markets abroad. Domestic markets for final goods are - not surprisingly more important for foreign affiliates in larger countries like the United States, the United Kingdom, France, etc. Important linkages between domestic SMEs and foreign affiliates emerge in a lot of countries; for example, the production by foreign affiliates of intermediate inputs destined for local companies is especially important in Italy, the United States and Japan. 
Figure 8. Output use of foreign affiliates, individual countries, total economy 2014

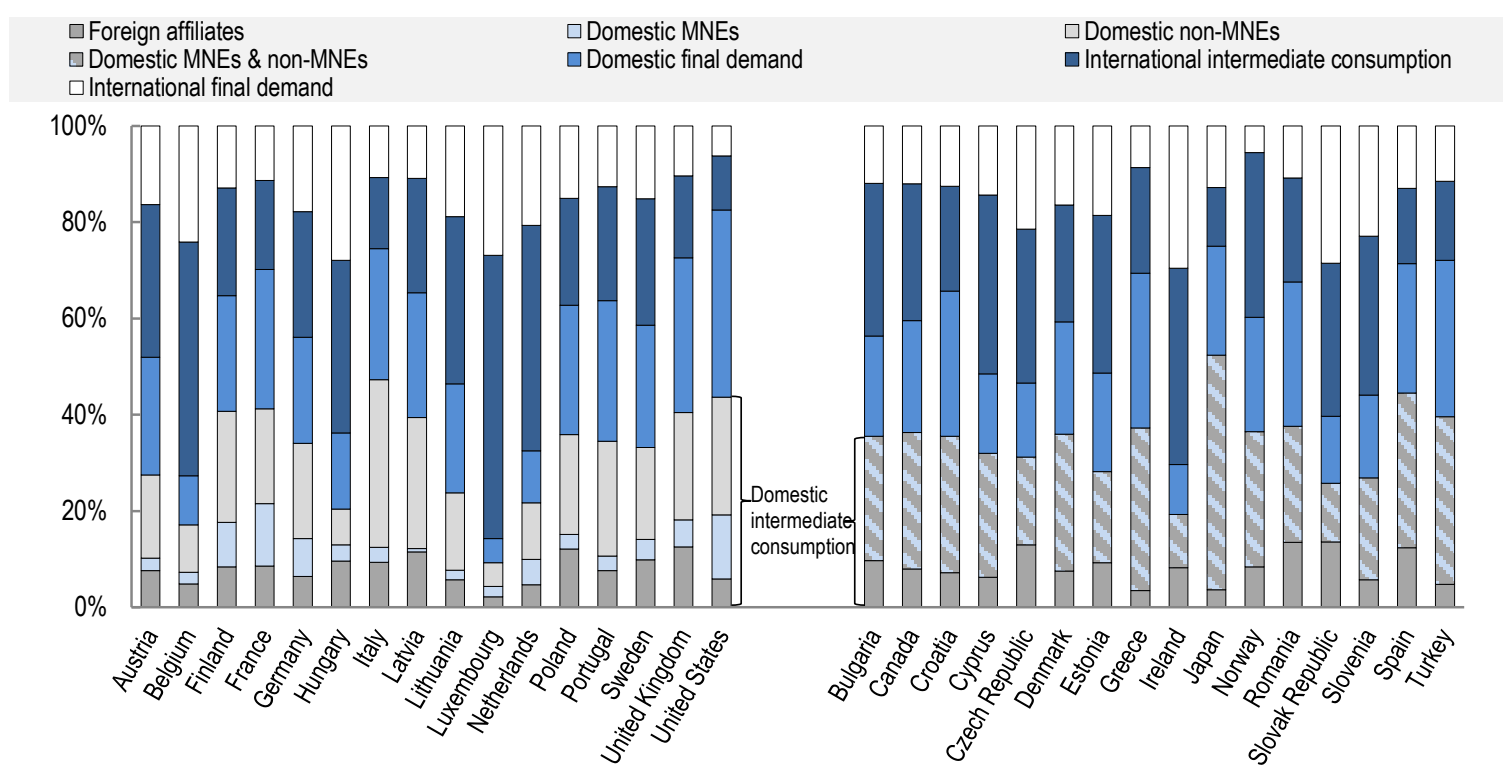

Note: Only countries are included for which official MNE data are available. The first group of countries publishes data on foreign affiliates as well as domestic MNEs, hence results are presented for domestic sourcing from foreign affiliates, domestic MNEs and non-MNEs. The second group of countries publishes only data on foreign affiliates, hence results are presented for domestic sourcing from foreign affiliates and domestic companies (MNEs and non-MNEs together).

1. Note by Turkey:

The information in this document with reference to "Cyprus" relates to the southern part of the Island. There is no single authority representing both Turkish and Greek Cypriot people on the Island. Turkey recognises the Turkish Republic of Northern Cyprus (TRNC). Until a lasting and equitable solution is found within the context of the United Nations, Turkey shall preserve its position concerning the "Cyprus issue."

2. Note by all the European Union Member States of the OECD and the European Union:

The Republic of Cyprus is recognised by all members of the United Nations with the exception of Turkey. The information in this document relates to the area under the effective control of the Government of the Republic of Cyprus.

Source: Calculations based on the OECD Analytical AMNE database.

The use of foreign affiliates' output is also very heterogeneous across individual industries (Figure 9). Goods manufactured by foreign affiliates are relatively more exported to international markets: $20 \%$ as final goods and $27 \%$ as intermediate goods in 2014. In manufacturing industries like "electrical", "machinery" and "electronic \& optical", even more than $50 \%$ of foreign affiliates' output is destined for international markets. In other industries like "wood", "paper and printing" and "mineral products", foreign affiliates are observed to produce especially inputs for the domestic market.

Services produced by foreign affiliates are particularly destined for the domestic market: $37 \%$ and $46 \%$ of foreign affiliates' production in 2014 was directed to domestic value chains respectively as final and intermediate services. Forward domestic linkages of foreign affiliates are particularly important in industries like "warehousing \& transport support", "postal \& courier" and "professional and scientific services". 
Figure 9. Output use of foreign affiliates, world, by industry, 2014

\section{Manufacturing}

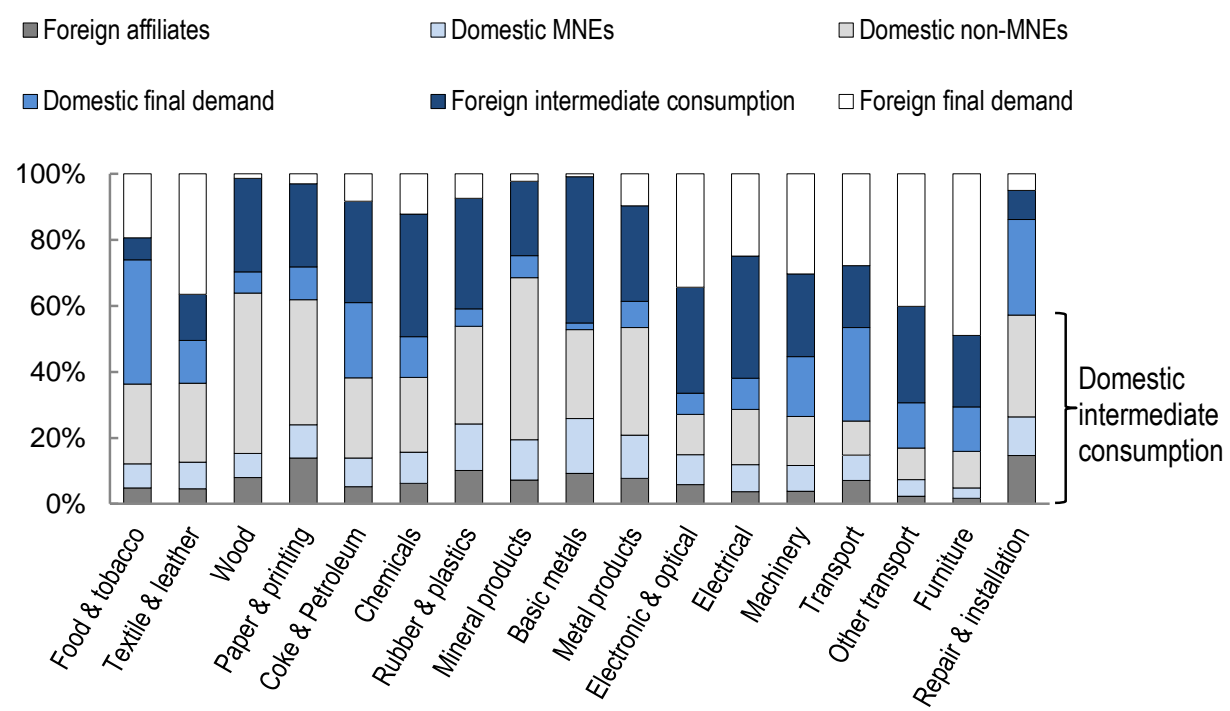

Services

$\square$ Foreign affiliates

$\square$ Domestic MNEs

$\square$ Domestic non-MNEs

$\square$ Domestic final demand

— Foreign intermediate consumption

$\square$ Foreign final demand

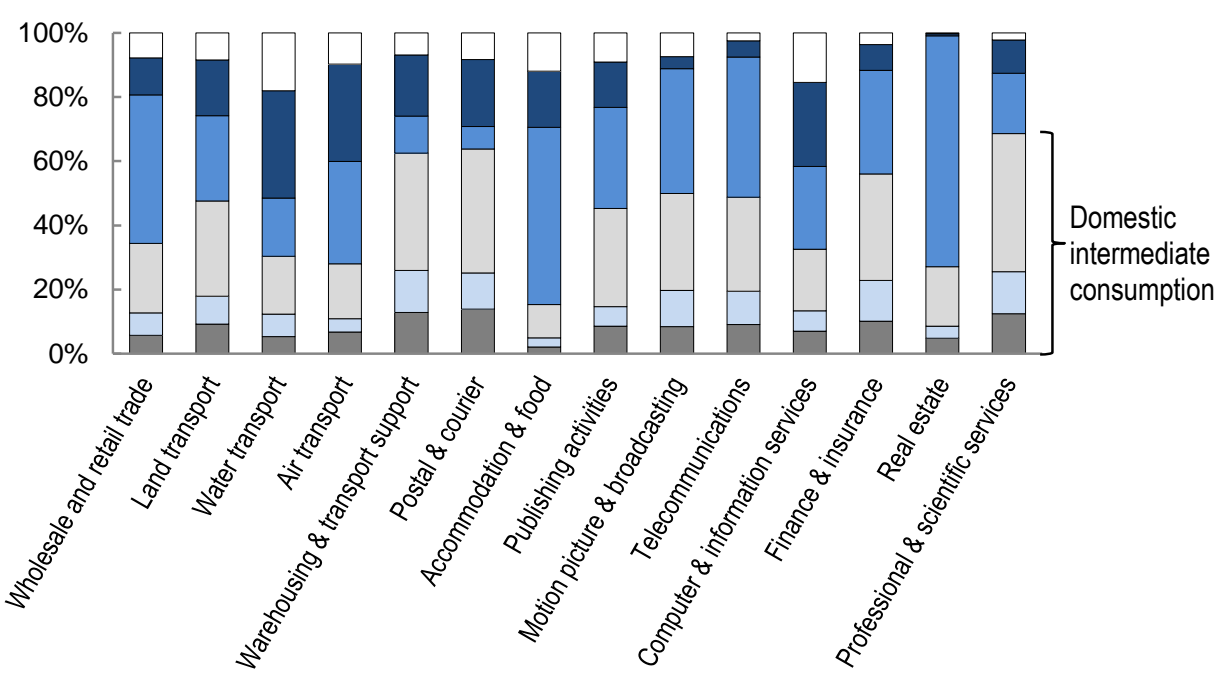

Source: Calculations based on the OECD Analytical AMNE database. 


\section{A more systematic look at indirect effects through input-output multipliers}

\subsection{Backward (output) multipliers}

In order to analyse relationships between industries, the concept of multipliers has been introduced in the input-output literature. The idea is to estimate how a change in final demand in a specific industry (in the case of backward multipliers) affects the activity of other industries. For example, if consumers spend one additional dollar in an industry, the backward multiplier calculates how many extra dollars of output are induced in upstream industries supplying inputs ${ }^{8}$. A higher demand for the products of that industry will directly result in an increase in the output of that industry, but indirectly also on the output of supplying industries down the supply chain (hence the multiplying effect in terms of output). The more integrated the industry is with the rest of the economy, the higher the multiplier. As such, multipliers can also be interpreted as indicators of economic integration.

As this paper focuses on the domestic linkages of MNE affiliates in host economies, similar backward output multipliers have been calculated to measure the effect of an increase in the final demand for products of MNE affiliates. Given the OECD analytical AMNE database allows to distinguish between different types of companies (domestic non-MNEs, domestic MNEs and foreign affiliates in a country), we can create a multiplier for each type of company but also decompose it for different types of suppliers.

Figure 10 shows that, at the global level, an extra-dollar of sales for foreign affiliates generated in 2014 on average an additional USD 0.62 for the domestic host economy. The total backward multiplier is 1.62 consisting of a USD 1 direct effect and a USD 0.62 indirect effect on the domestic economy. This indirect effect stems from the important domestic sourcing links of foreign affiliates in host countries.

Further distinguishing between the type of suppliers, USD 0.49 (out of the USD 0.62) accrued to domestic firms in 2014 because of the larger sourcing by foreign affiliates from domestic suppliers $\left(\right.$ see above $^{9}$ ). The other USD 0.13 benefitted the group of foreign affiliates in host economies as there is also sourcing among foreign affiliates. The group of domestic SMEs is the largest beneficiary of these indirect effects as about $75 \%$ of the USD 0.41 going to domestic suppliers goes to domestic non-MNEs. 
Figure 10. Backward output multiplier of foreign affiliates, world average, total economy

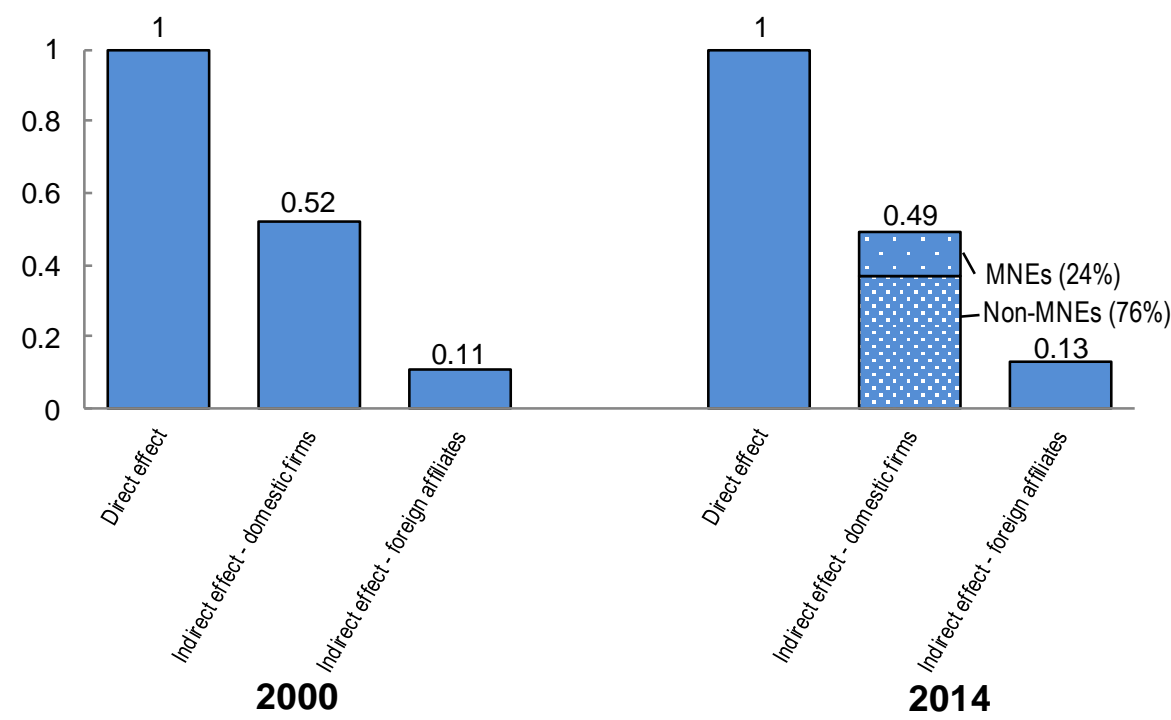

Note: average weighted across industries unweighted across countries,

Source: Calculations based on the OECD Analytical AMNE database.

The growing importance of GVCs and the larger offshoring of intermediates is reflected in the (slightly) decreasing size of the (domestic) backward multiplier over time. The composition of the multiplier has also changed somewhat with the effects for domestic suppliers (slightly) shrinking while these of foreign affiliates (in the host economy) growing.

Backward multipliers of foreign affiliates are largely similar for manufacturing and services industries (Figure 11). One extra dollar of foreign affiliate final demand created in 2014 respectively USD 0.46 and USD 0.43 to domestic suppliers in manufacturing and services (and USD 0.11 and USD 0.12 to foreign affiliates in manufacturing and services). Also the effects on domestic MNEs and non-MNEs are largely the same across both groups of industries. Further disentangling these effects demonstrates the growing phenomenon of servicification in line with previous OECD work (De Backer et al., 2015; Miroudot and Cadestin, 2017; Andrenelli et al., 2018): for an extra dollar of goods sold by foreign affiliates, firms providing services benefit more than manufacturing firms (USD 0.24 versus USD 0.23 respectively). 
Figure 11. Backward output multiplier of foreign affiliates, manufacturing and services, 2014

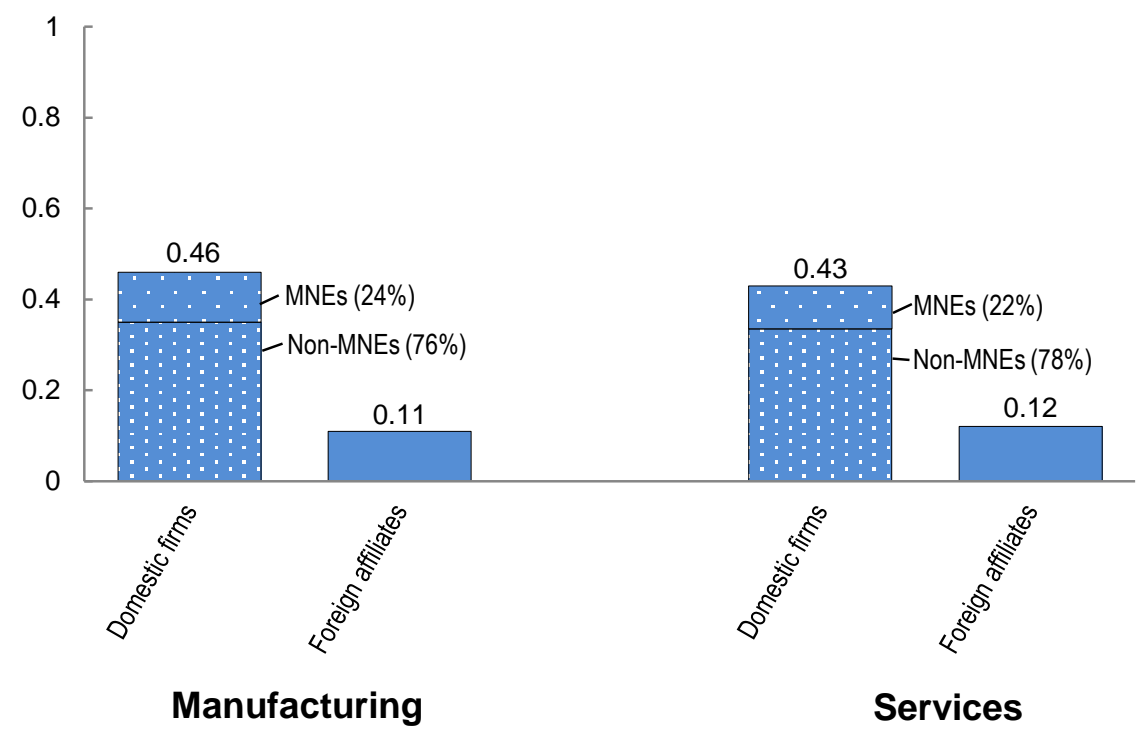

Note: average weighted across industries unweighted across countries, Source: Calculations based on the OECD Analytical AMNE database

The backward multipliers for individual countries and industries are presented in Annex 2. The results are consistent with these presented in figures 4 and 5, showing for example a large multiplier of foreign affiliates on domestic non-MNEs in Italy. At the industry level, services show on average larger backward multipliers reflecting the larger sourcing from within the domestic economy while manufacturing industries source relatively more internationally. 


\section{Box 2. Backward linkages of domestic MNEs}

An interesting (policy) question that can be addressed by the analytical AMNE database is whether domestic MNEs have stronger backward linkages than foreign affiliates in host countries. On the one hand, the literature has largely demonstrated that the very nature of a MNE is more important than country of ownership in explaining characteristics across firms (i.e. between domestic non-MNEs, domestic MNEs and foreign affiliates). Previous research involving data from different countries has reported rather small differences in terms of size, productivity, capital intensity, etc. between foreign affiliates and domestic MNEs, while typically large(r) differences between domestic non-MNEs on the one hand and foreign affiliates and domestic MNEs on the other hand. Following this argument, only smaller differences in backward linkages could be expected between domestic and foreign MNEs.

On the other hand, it can be hypothesised that domestic linkages of domestic MNEs will be larger because of their historical growth in their home country. Furthermore, strong(er) domestic linkages with suppliers and customers often have helped domestic MNEs to internationalise their activities.

The results indeed show that backward multipliers of domestic MNEs are somewhat larger than of foreign affiliates. For the total domestic economy, an extra USD 1 of final demand for domestic MNEs results in another 0.72 extra dollar for the rest of the economy while the extra dollar for foreign affiliates generates an additional USD 0.62 domestically in the home country. Focusing specifically on domestic SMEs, the respective multipliers for domestic MNEs and foreign affiliates are 0.43 and 0.36 (2014 figures).

\section{Backward (output) multipliers of foreign affiliates and domestic MNEs, world average, total economy, 2014}

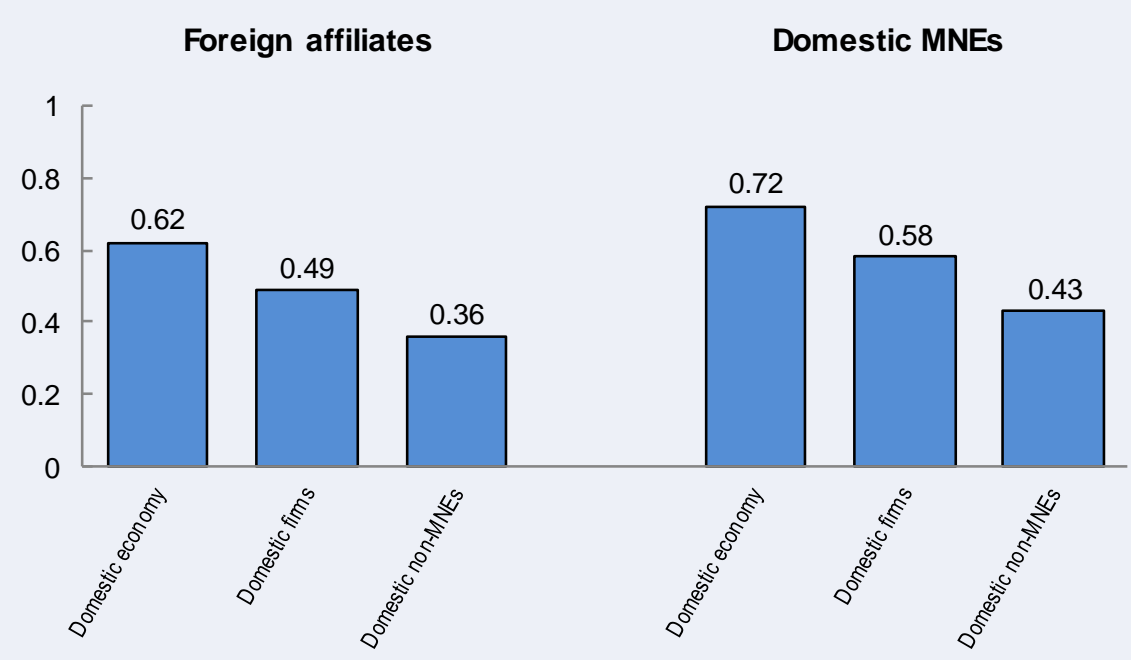

Note: only indirect effects presented; unweighted across countries

Source: Calculations based on the OECD Analytical AMNE database. 


\subsection{Forward (output) multipliers}

Multipliers can also be calculated for forward linkages. Instead of looking at the impact of an increase in final demand on upstream industries, forward multipliers look at how an increase in the supply of inputs in a given industry impacts downstream industries and the demand for final goods and services ${ }^{10}$. As in the previous section, we apply the concept of forward multipliers to the output of foreign affiliates in order to measure the increase in the output of domestic companies down the supply chain following an increase in the provision of inputs by foreign affiliates. The growing availability of factor supplies for foreign affiliates generates an increase in foreign affiliates' output, which is partially bought as intermediate inputs allowing domestic companies to similarly increase their output.

The results in Figure 12 show a forward multiplier of 1.86 in 2014, which has decreased from 2.02 in 2000. It implies that foreign affiliates are stimulating downstream industries relatively less over time. It can illustrate the growth of GVCs among others with affiliates having a higher impact on foreign sectors. However, the domestic impact is still strong. Forward multipliers are somewhat larger for domestic firms (non-MNEs as well as MNEs) than for other foreign affiliates. The results for individual countries and industries are included in the Annex 2.

Figure 12. Forward output multiplier of foreign affiliates, world average, total economy, 2014

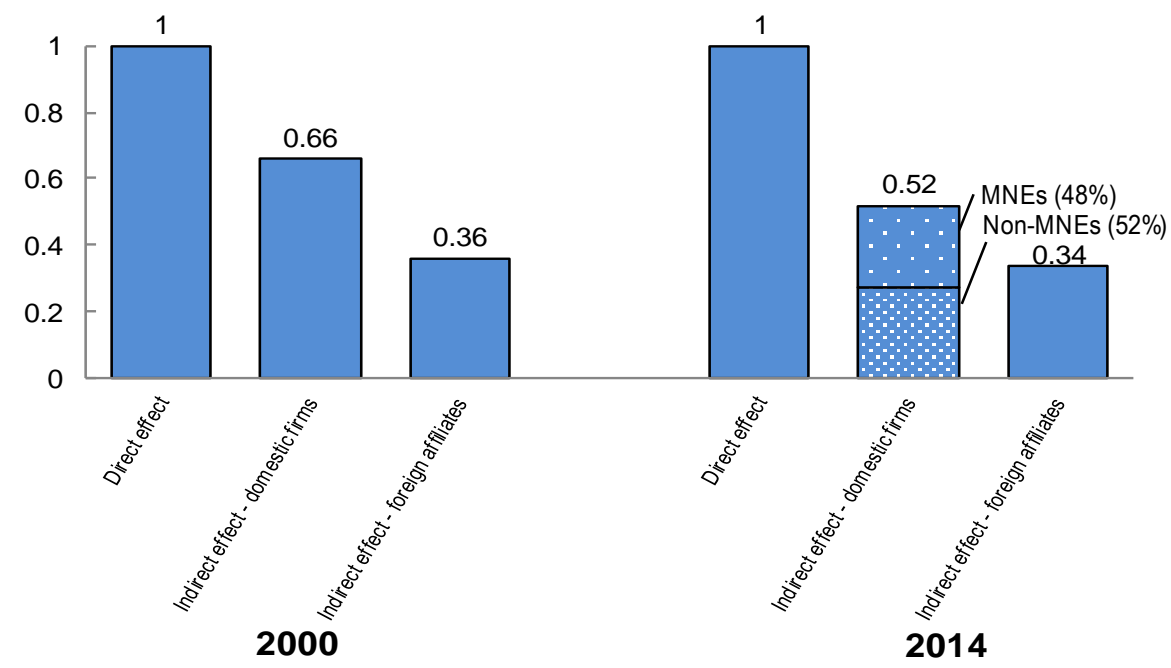

Note: average weighted across industries unweighted across countries,

Source: Calculations based on the OECD Analytical AMNE database.

\section{3. "What if?"}

The systematic information captured in IO multipliers can be used to "simulate" what would happen if foreign presence in host countries would change. For example, instead of focusing on the importance of foreign affiliates for the domestic economy, the multipliers also provide a tool to analyse the (short term) effects of the closure of a foreign firm. The large number of jobs - i.e. the direct effect - that results from such an exit typically attracts a lot of policy and media attention, but the effects upstream and downstream along the 
domestic value chain are easily overlooked. The backward multiplier in a certain country and industry will give a first insight in the indirect effects triggered within the domestic value chain. A multiplier of 0.70 means that per USD 1000 loss of output by the foreign affiliate that shuts down (or decrease) its activities in the country, another USD 700 loss of output could be expected in the domestic industry. Using other characteristics like productivity, vertical integration, etc., further estimates of job losses could also be derived.

It has to be stressed that such estimates are the outcome of a comparative static exercise without any reallocation across countries, industries and firms. Input-output tables and evidence based on this assume a "fixed" structure, hence not taking into account the reallocation of resources (employment, capital investment, etc.). In reality however, freed resources will move between economic actors across countries, industries and firms, often meaning that the actual effect will typically be smaller

IO multipliers can also be used in "thought" experiments, for example positing what a world without foreign affiliates would look like. The technique of "hypothetical extraction" is applied to simulate a global economy without MNE affiliates in host economies ${ }^{11}$. A first simulation removes all foreign affiliates across all industries and all countries from the global economy; following simulations remove foreign affiliates in individual sectors in the global economy as well as in individual countries.

If international investment were no longer present in the global economy, resulting in the removal of all foreign affiliates across all industries and countries, world GDP would decrease by $20.5 \%$ (based on 2014 figures), i.e. one fifth of world GDP. This percentage is considerably higher than the direct contribution of foreign affiliates to world GDP in Figure $1(10 \%)$, because this hypothetical extraction also takes into account the backward and forward effects of foreign affiliates. Given that foreign affiliates have important linkages with domestic value chains through customer and supplier relationships, their removal would directly impact the suppliers and customers of foreign affiliates' production.

At the industry level (Figure 13), important effects (above $40 \%$ of industry value added) are observed in "chemicals", "rubber and plastics", "electronic and optical equipment" "transport" and "repair and maintenance" - all manufacturing industries. The hypothetical effects are somewhat smaller in services industries but still important (more than 30\% of industry value added) in "warehousing and transport support", "computer and information services" and "finance and insurance". 


\section{Figure 13. Percentage GDP change, "A world without foreign affiliates”, individual} industries

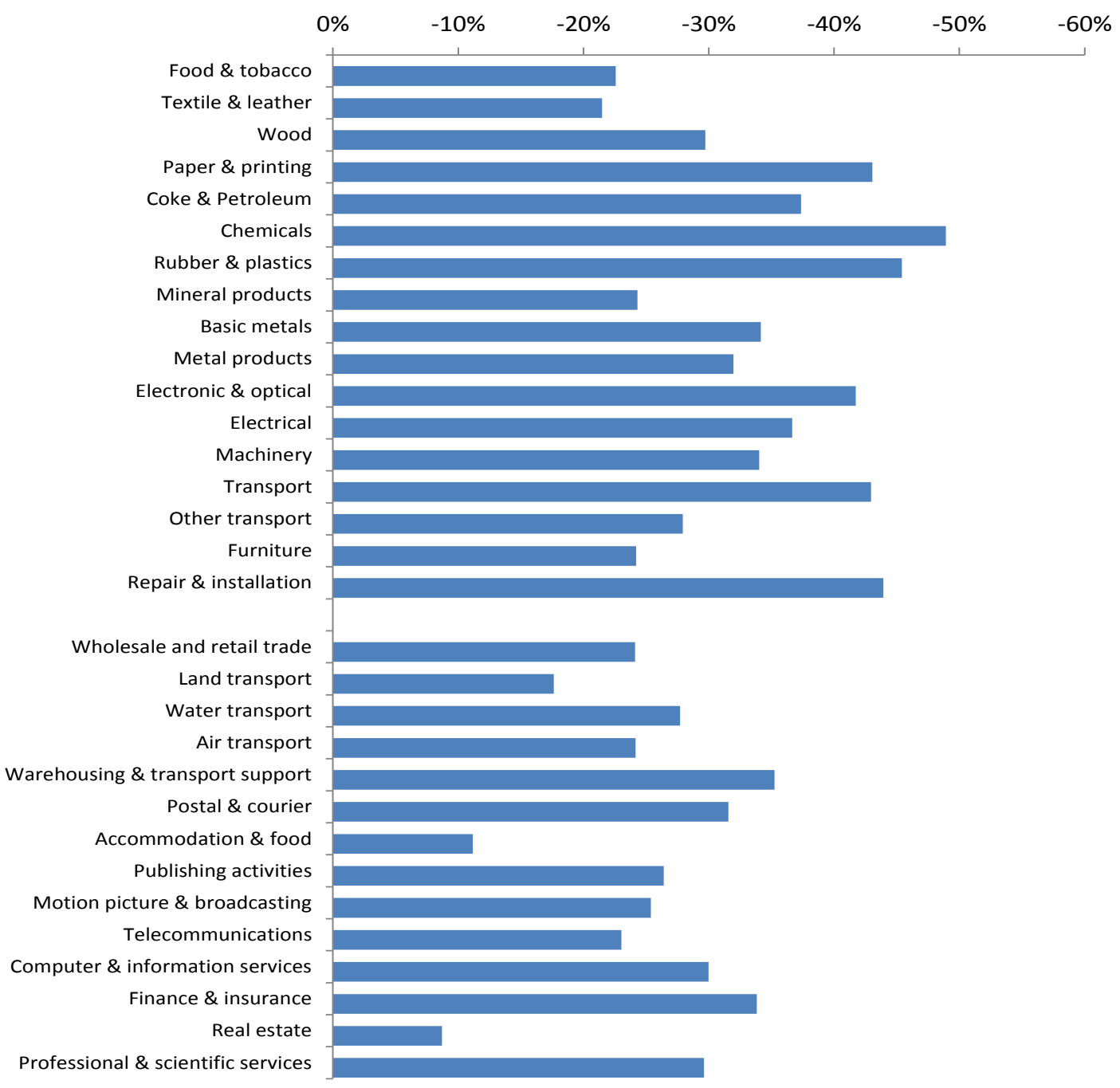

Source: Calculations based on the OECD Analytical AMNE database

At the country level (Figure 14), a number of - typically smaller - countries would experience a significant decrease (of $30 \%$ and more) in GDP if international investment was eliminated. In addition to Luxembourg and Ireland, especially Eastern European countries show a large drop in economic activity after removing foreign affiliates from their economies. These results show foremost the strong dependency of these countries on foreign investment for their integration in GVCs.

The estimated impacts in this hypothetical extraction exercise are the combined of the (relative) size of foreign affiliates in national economies - i.e. the direct effect - and their linkages in domestic value chains - i.e. the indirect effects. The integration of foreign affiliates in domestic value chains will ceteris paribus make that foreign affiliates are less likely to leave - because of their strong customer and/or supplier relationships. But at the other side, in case of their stopping (or reducing) activities, departure will result in a larger impact on the host economy. 
Figure 14. Percentage GDP change, "A world without foreign affiliates", individual countries

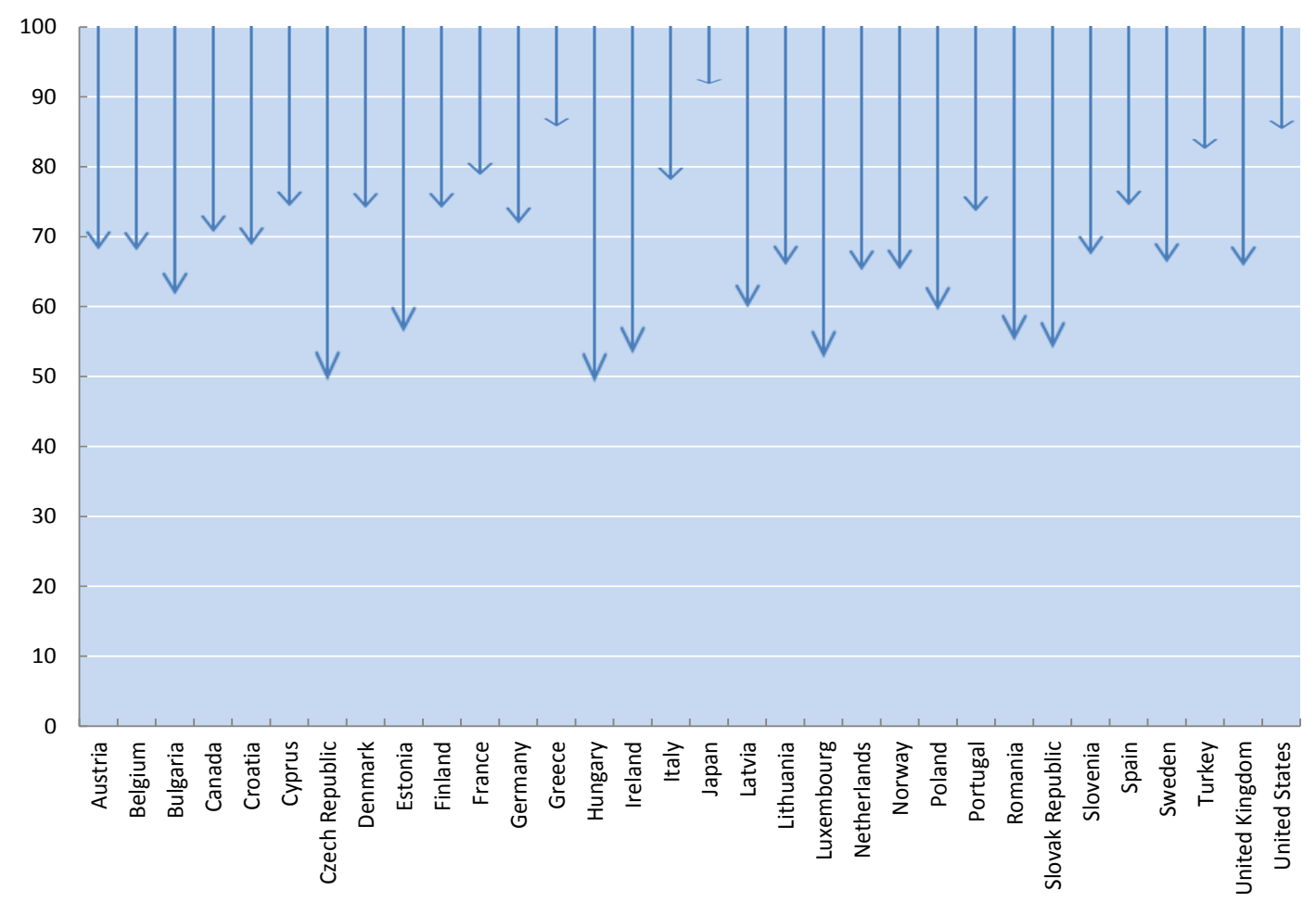

Source: Calculations based on the OECD Analytical AMNE database.

The differences across industries and countries become even clearer when analysing the effects of specific industries in individual countries. For example, in the transport manufacturing (including automotive) sector - an industry characterised by a strong foreign presence - the exit of foreign affiliates would almost completely (-97\%) wipe out the industry in Hungary (data for 2014). The reason is that foreign affiliates account for $95 \%$ of the value added created in this industry. The effect on the Italian transport manufacturing industry is significantly smaller - but still considerable: $-44 \%$ - as foreign affiliates account for "only" $27 \%$ of industry value added. But in contrast to Hungary, important backward (and forward) linkages exist between foreign affiliates and domestic suppliers.

Again, the correct interpretation of the results of such hypothetical thought experiments has to be stressed. Given the methodology is based on IO tables, the outcomes result from a "fixed" production structure and no resource reallocation. In reality, however, the departure of foreign affiliates would free up important resources and result in less competition which will through changes in prices, supply and demand alter the structure of national economies. Domestic firms would take the place of foreign affiliates, albeit partially, thereby compensating to some extent the reported effects. The timing and the size of the (final) GDP change will depend among other things on the similarity between domestic firms and foreign affiliates (in terms of technology, knowledge, etc.). 


\section{Policy discussion and implications}

This paper provides - for the first time - comprehensive and detailed insights on the importance and role of MNEs and their affiliates abroad, based on new evidence developed within the OECD analytical AMNE database. As emphasised in the paper, there are caveats in the analysis and the database relies on assumptions and estimates for missing data. Going forward, the database will be improved and will benefit from current efforts by national statistical offices in the improvement of national accounts and AMNE statistics. As such, this report provides initial findings based on the first version of the database.

A first result is that MNE affiliates in host countries generate important direct effects in terms of output, value added, international trade and jobs. Domestic MNEs - i.e. headquarters and domestic plants in the home country of the MNE - have similar if not larger direct effects. This new evidence indicates that MNEs account roughly for one-half of international trade, one-third of output and GDP and one-fourth of employment in the global economy.

But MNE affiliates also generate important indirect effects dependent on how strongly integrated they are into domestic economies. On average at the global level, every dollar of extra sales for foreign affiliates generates another USD 0.51 for the domestic economies where they are located. Differences exist across countries and industries, but the assertion that foreign affiliates operate isolated in host countries and source all intermediate goods and services from within their MNE network does not seem to be supported by the data. Instead, foreign affiliates contract and co-operate increasingly with domestic suppliers, including SMEs, in their operations.

The results demonstrate the importance of foreign affiliates in domestic value chains, not only as consumers of locally produced inputs, but also as suppliers of final and intermediate products sold and used within the domestic economy. Foreign affiliates can be considered as an important gateway to international markets and connect the domestic and international parts of GVCs. They function at the crossroads of domestic and global markets and make the link between (purely) domestic and international activities. The success of MNE affiliates and their international operations benefit directly and indirectly the domestic economy where they are located.

From a domestic economy perspective, the results also demonstrate the importance of domestic value chains. As highlighted in the analysis, for each job abroad in their foreign affiliates, MNEs (still) have more than two jobs at home clearly demonstrating that multinational production abroad is not detrimental to job creation at home. Further on, jobs are created domestically also indirectly through the suppliers of MNEs. The domestic part of the value chain is often as important as its foreign part, since MNEs frequently rely on SMEs to become global firms and expand internationally.

Competitive national economies harbour domestic firms (which are to a large extent SMEs), domestic MNEs as well as foreign affiliates, reflecting economies' attractiveness for doing business locally. Policies need thus to be inclusive for the different types of companies. Creating incentives for some companies to participate in GVCs e.g. on the presumption that international active companies provide important benefits to the host economy - while largely ignoring domestic companies involved in the value chain, is not an effective policy approach. It is therefore important to create a conducive domestic policy environment for firms of all size and engaged in all types of operations (international or 
domestic). Policies related to access to capital, skills, innovation, and the simplification of administrative procedures, to name a few, are key, as is the development of physical and virtual infrastructure.

Increasing the attractiveness for foreign investment has been a policy priority for many countries during the past decades. OECD as well as non-OECD countries have introduced a wide range of policy measures to attract foreign MNEs. The policy mix differs between countries but generally covers broader policy instruments for economic development (e.g. provision of land and infrastructure, development of domestic technology and knowledge centres, $(\mathrm{R} \& \mathrm{D})$ tax incentives, etc.) as well as specific government incentives (e.g. direct financial support and general fiscal incentives) and investment promotion policies (e.g. active recruitment of foreign MNEs, advertising). Previous OECD work on "Attractiveness for Innovation: Location Factors for International Investment" (OECD, 2011) as well as the OECD Policy Framework for Investment $(\mathrm{PFI})^{12}$ have discussed these policies in more detail.

In addition to these "attractiveness" policies for foreign investment, several countries have also used specific policies to stimulate linkages between foreign affiliates and the domestic economy. The importance of domestic linkages between MNE affiliates and domestic suppliers and their (in)direct effects on host economies is often used as an argument in favour of policy intervention ${ }^{13}$. In the absence of strong linkages, international investment may generate only limited effects and in some industries operate as an "enclave" within the host economy. Furthermore, previous research has shown that when linkages are present, they often lead to direct knowledge and technology transfers (i.e. spillovers). International investment is also seen by some policy makers as a quick way to get access to GVCs and to upgrade industrial activities. Nevertheless, an important result in this paper is that that domestic linkages of domestic MNEs are as important - and even more - as these of foreign affiliates, hence cautioning for policies exclusively targeted at foreign companies.

Again policies to stimulate linkages between foreign affiliates and domestic firms differ across countries, but some general types of policies can be distinguished. First, information building and sharing on possible and future supply opportunities is crucial. Linkages between foreign affiliates and domestic firms rarely happen on their own, hence there is a clear need for policy action often in close co-operation with industry associations. A large part of domestic suppliers are SMEs which are often constrained by resources (and time) while new MNE affiliates may be unfamiliar with the local business environment. Initiatives to promote information exchange and raise awareness of foreign affiliates' requirements (e.g. adherence to standards, etc.) to local firms and of local firms' existence to foreign firms have proven to be helpful. A knowledge base of domestic suppliers for example could be an asset in attracting new international investments. Several countries have implemented so-called SME linkage programmes: initiatives like business matchmaking services and activities, international trade fairs, the creation of e-commerce platforms, vendor training, incubator and SME centres, support to acquire (product) quality certification, etc. are all intended to link domestic firms to MNE affiliates.

Second, the creation of domestic linkages is dependent on the capabilities of domestic suppliers. In order to respond to the production needs of MNEs, the absorptive capacity of domestic firms will need to be reinforced. Government support to education, training, innovation, etc. will help domestic companies to connect and co-operate more intensively with MNE affiliates.

Third, recent years have witnessed a substantial increase in the use of local content requirements (LCRs) - i.e. policies imposed by governments that require firms to use 
domestically manufactured goods or domestically supplied services in order to operate in an economy. The motivation of such policies is often directly linked to the creation of domestic linkages by foreign affiliates with domestic suppliers and customers, but previous research has shown that LCRs also undermine long-term industrial competitiveness (Stone et al., 2015). Stronger domestic linkages are created when foreign firms find competitive partners in the domestic economy.

Fourth, in addition to targeted tax incentives to attract international investment, a number of countries have introduced specific tax incentives to promote SME linkages. Within ASEAN for example, Singapore, Malaysia and Thailand, have introduced specific tax incentives to promote SME linkages, skills, environmental protection, $R \& D$, automation and high-tech activities (OECD, 2018) ${ }^{14}$. Not much research has been undertaken yet on the effects of such incentives, hence it is difficult to assess the effectiveness and efficiency of this type of policy measures.

The paper and particularly the empirical evidence developed in the analytical AMNE database opens new avenues for further research. First, more detailed data on foreign affiliates will help policy makers to better understand the importance and dependency of domestic value chains on the presence of foreign affiliates. The participation and upgrading in GVCs is in some countries closely related to the activities of foreign affiliates. The evidence developed in the database also allows to "model" a number of scenarios through the use of multipliers to analyse what could happen if foreign affiliates decide to expand or contract - or even completely stop like in the hypothetical extraction analysis - their activities in specific industries and countries.

Second, better insights in the domestic linkages between MNEs and the domestic economy, may contribute to the large spillovers literature. Better data on spillovers channels allow for a more detailed measurement and thus appropriate discussion of MNE spillovers. Third, the evidence that domestic linkages differ across countries and industries raises the inevitable "why" question: what are the determinants at the country and industry level that result in larger and closer linkages between MNEs and domestic firms. And can policy impact on them? 


\section{Annex A. Methodology}

This annex contains information on the methodology used to produce the different estimates reported in the document. All the data are sourced from the OECD analytical AMNE database ${ }^{15}$, which is a database developed internally by combining the WIOD international input-output tables (Timmer et al., 2015) with the OECD AMNE database. Detailed information on the construction of this database is available in Cadestin et al. (2018a).

This exercise has produced an international input-output table split according to firm ownership. Two versions were created, one where all data are split into two parts (domesticowned and foreign-owned firms) and for more recent years one where a further split is introduced among domestic-owned firms (domestic MNEs and non-MNEs). Following the AMNE definition, a firm is considered as foreign when its ultimate owner - owning more than $50 \%$ of the value of the firm - is a non-resident.

Statistics of this report are based on the 2-part version and all figures distinguishing domestic MNEs from non-MNEs incorporate shares for MNEs in domestic output coming from the 3-part version. The reason is that the tables split into 3 parts contain more estimates and results from the 2-part tables are more robust.

This database contains information for 44 countries among which 32 have available information on activities of foreign affiliates ${ }^{16}$ and 16 have information on domestic $\mathrm{MNEs}^{17}$.

The report relies on two indicators that use the Leontief inverse. The first indicator is the Leontief multiplier. It corresponds to the output that is implied in the economy by the sale of a final product. To generate this indicator, the Leontief matrix is calculated from the analytical AMNE input-output table split into 2 parts. The multiplier for a given country, sector and industry corresponds to the sum along the column of this Leontief matrix.

Second, the hypothetical extraction method consists in calculating the hypothetical GDP when foreign affiliates sales are set to zero. GDP_s=v_s. $\left(\mathrm{I}-\mathrm{A}^{\wedge *}\right)^{\wedge}(-1) \cdot \mathrm{y}^{\wedge *}$ where $\mathrm{v} \_\mathrm{s}$ is the vector of the ratio of value added on output, $\mathrm{A}^{\wedge *}$ and $\mathrm{Y}^{\wedge *}$ are respectively the matrix of technical coefficients and the final demand vector where foreign affiliates sales are set to zero. 


\section{Annex B. Additional Figures}

\section{Figure B.1. Backward output multiplier of foreign affiliates, individual countries, total} economy average, 2014

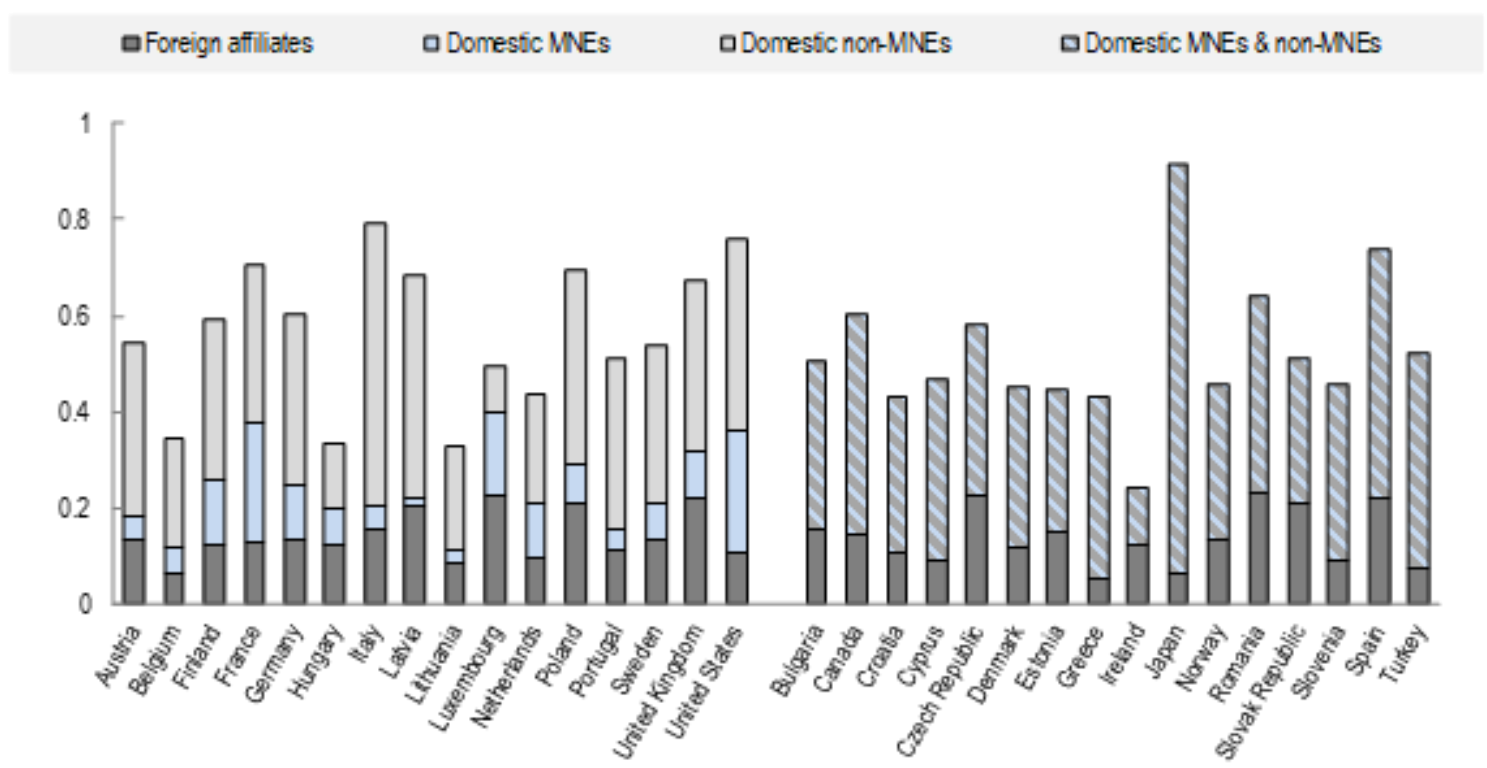

Note: Add the note here. If you do not need a note, please delete this line.

Source: Add the source here. If you do not need a source, please delete this line.

Note: only indirect effects presented; weighted across industries

1. Note by Turkey:

The information in this document with reference to "Cyprus" relates to the southern part of the Island. There is no single authority representing both Turkish and Greek Cypriot people on the Island. Turkey recognises the Turkish Republic of Northern Cyprus (TRNC). Until a lasting and equitable solution is found within the context of the United Nations, Turkey shall preserve its position concerning the "Cyprus issue."

2. Note by all the European Union Member States of the OECD and the European Union:

The Republic of Cyprus is recognised by all members of the United Nations with the exception of Turkey. The information in this document relates to the area under the effective control of the Government of the Republic of Cyprus.

Source: Calculations based on the OECD Analytical AMNE database 
Figure B.2. Backward output multiplier of foreign affiliates, world average, individual industries, 2014

\section{Manufacturing}

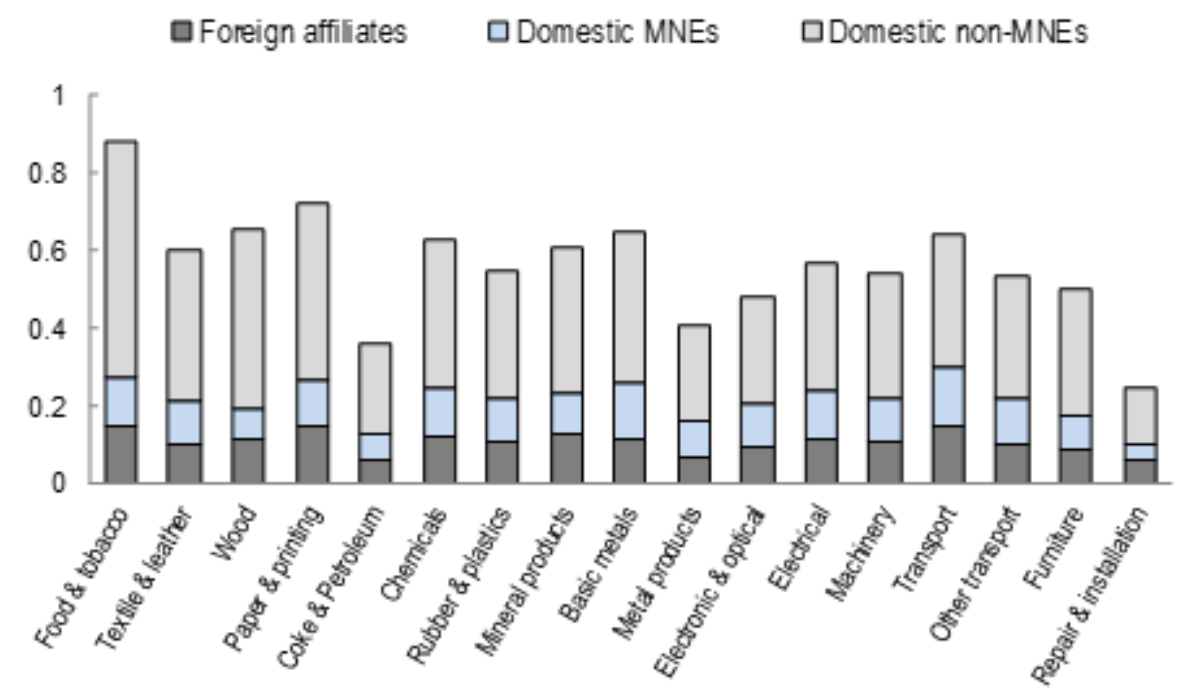

Figure B.3. Services

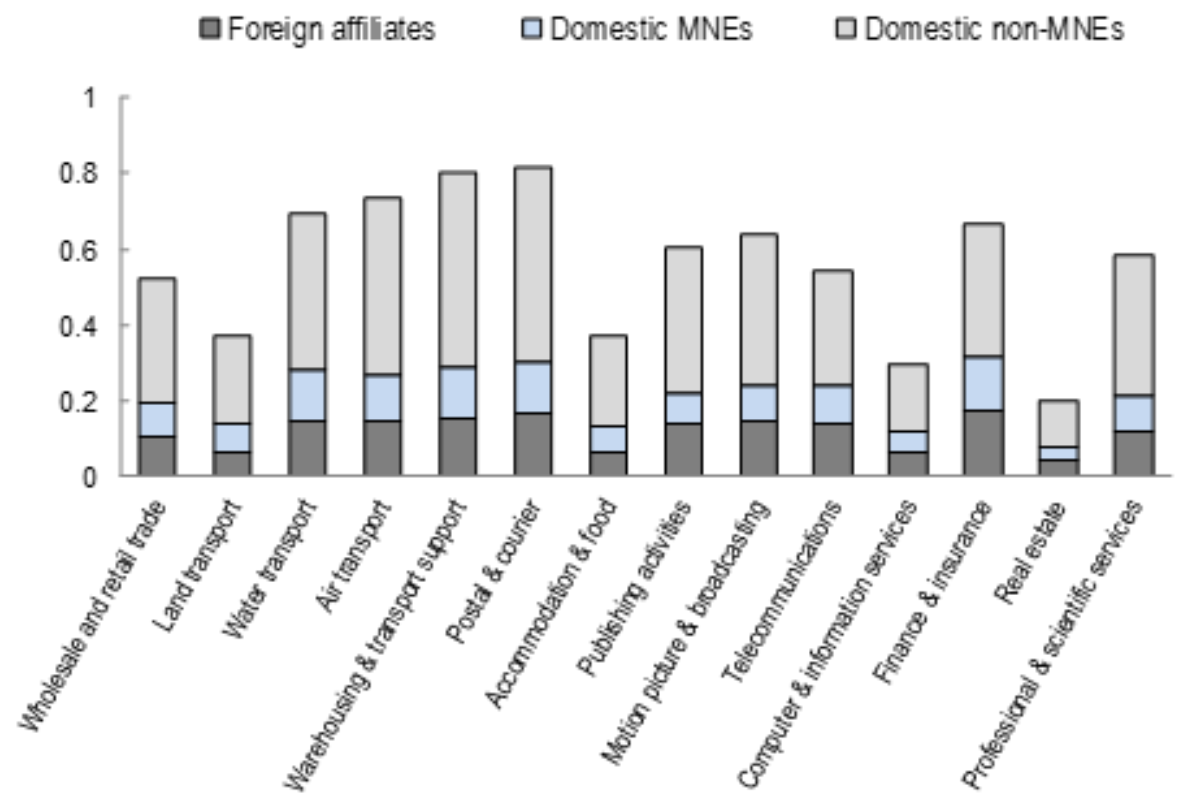

Note: only indirect effects presented; unweighted across countries

Source: Calculations based on the OECD Analytical AMNE database 
Figure B.4. Forward output multiplier of foreign affiliates, individual countries, total economy, average, 2014

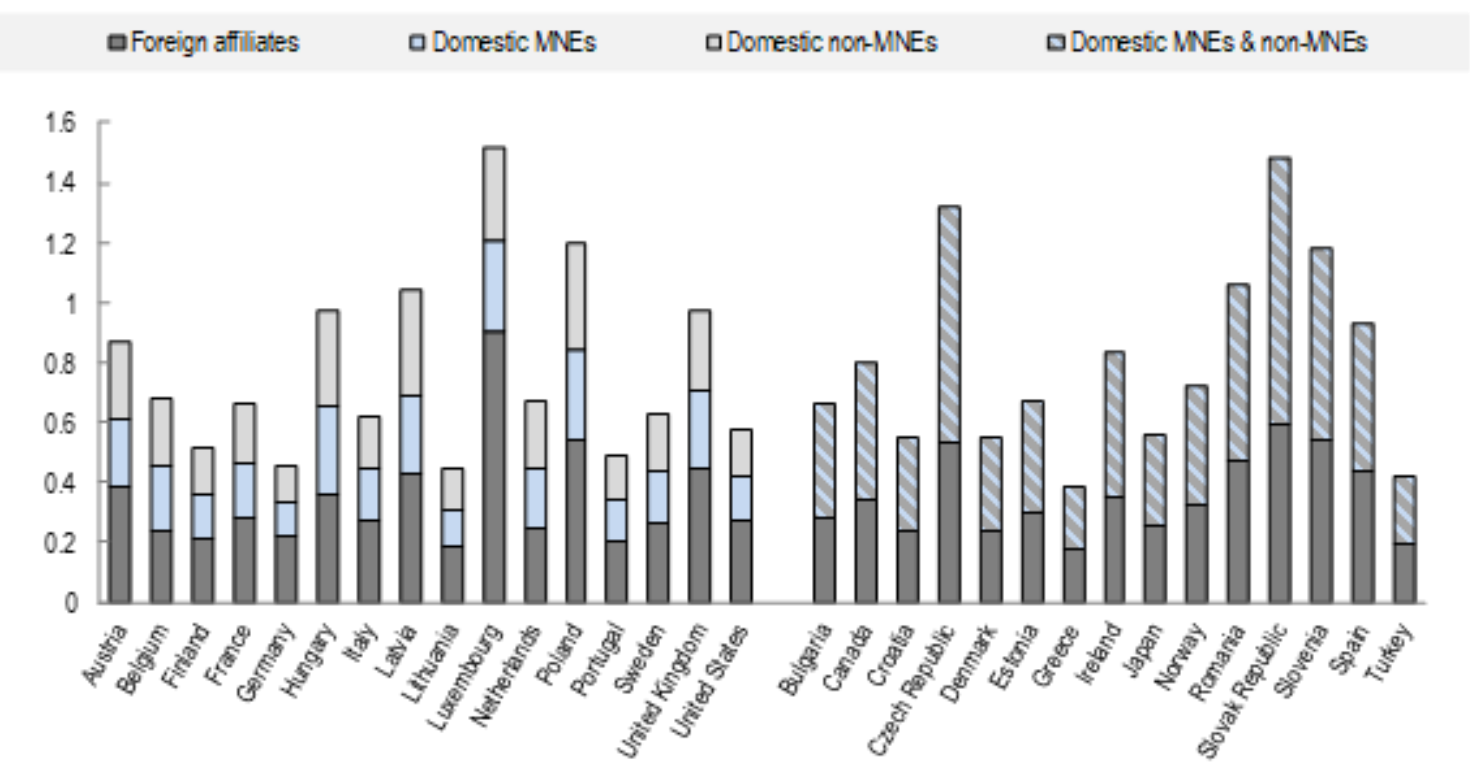

Note: only indirect effects presented; weighted across industries

Source: Calculations based on the OECD Analytical AMNE database 
Figure B.5. Forward output multiplier of foreign affiliates, world average, individual industries, 2014

\section{Manufacturing}

aForeign affiliates $\quad$ Domestic MNEs $\quad$ Domestic non-MNEs

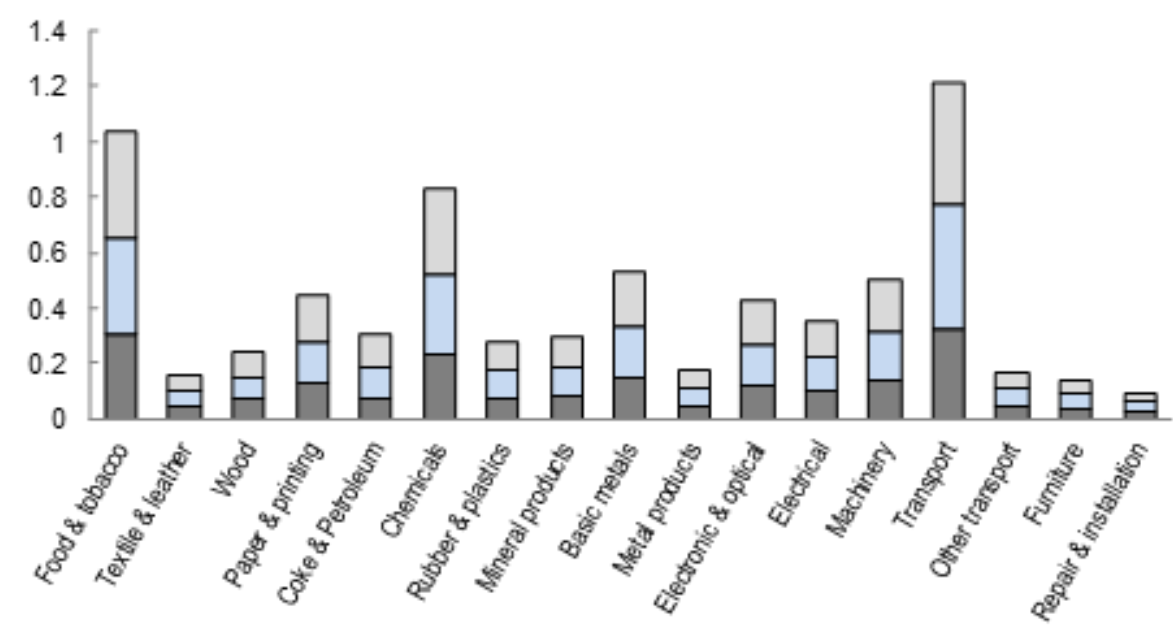

Figure B.6. Services

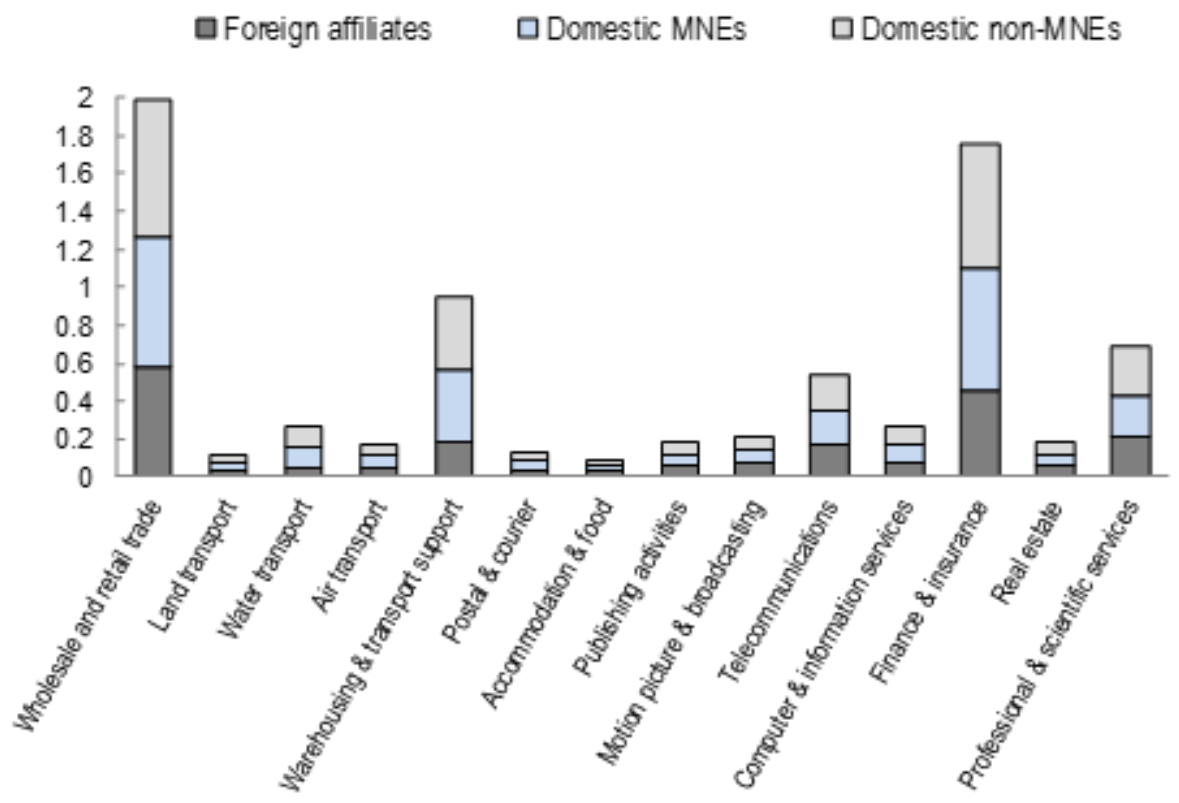

Note: only indirect effects presented; unweighted across countries

Source: Calculations based on the OECD Analytical AMNE database 


\section{Notes}

1 "Knowledge flows (...) are invisible; they leave no paper trail by which they may be measured and tracked, and there is nothing to prevent the theorist from assuming anything about them that she likes" (Krugman, 1991, p. 53).

${ }^{2}$ All the data used in this report are estimates from the OECD analytical AMNE database. See Annex 1 for more details and http://oe.cd/gvc-mne.

3 Throughout the paper, 3 different groups of firms are distinguished: foreign affiliates, domestic MNEs - i.e. MNE headquarters and domestic plants of these groups - and domestic non-MNEs.

${ }^{4}$ One part of that value added is used to pay the salaries for the (mostly local) employees of MNEs and thus "sticks" to the domestic economy, while another part, including their earnings, may or may not leave the host country.

${ }^{5}$ Small and medium sized enterprises make up for the majority of firms in national economies. Dependent on the definition of SMEs (firms with less than 50 or 250 employees), SMEs account respectively for $98.2 \%$ or $99.8 \%$ of all companies although their importance in employment, value added and output is (much) smaller (data for 2014, OECD (2017), Entrepreneurship at a glance). No official data on the presence of SMEs in each of the 3 groups of firms distinguished in this paper are available. But as previous research has demonstrated that MNEs are typically larger than the average domestic firms, it can be expected that the above mentioned percentages will even be higher for the group of domestic non-MNEs.

${ }^{6}$ BRIICS countries include Brazil, Russia, India, Indonesia, People's Republic of China and South Africa.

${ }^{7}$ The OECD analytical AMNE database includes estimates for missing information (at countryindustry level) which have been used to derive the global results presented in the previous and following graphs.

${ }^{8}$ The output multiplier is expressed as the ratio of direct and indirect output changes to the direct output change due to a unit increase in final demand. Multiplying a change in final demand (direct impact) with the backward multiplier will generate estimates of the indirect impacts in terms of output for the specific industry.

${ }^{9}$ In contrast to the previous section, these figures take into account further effects down the supply chain (second, third, fourth and other rounds) and also include the effects on the industries supplying inputs to the (domestic) industries directly supplying the foreign affiliates in host economies.

10 These forward multipliers are less used as they depart from a demand-driven model where final demand is exogenous and assume a supply-driven model where the supply of inputs can increase consumption at the end of the value chain. Such approach is less realistic and has issues highlighted in the input-output literature. However, we can still use these multipliers as indicators of economic integration ex-post, not expecting that stimulating the supply of inputs would increase demand.

11 The technique was originally developed by Paelinck et al. (1965) and Miller (1966) quantifies how much the output in an economy would decrease if a particular industry was no (longer) present, i.e. when this industry is deleted from the national economy system. The method uses Input-Output 
Tables by setting the row (forward linkages) and/or column (backward linkages) describing the industry in question in the accounts to zero; the difference before and after extraction indicates the importance of the extracted industry to the national economy.

12 http://www.oecd.org/investment/pfi.htm

${ }^{13}$ In addition, the presence of strong suppliers is also an important factor in the attractiveness of countries for foreign investment.

${ }^{14}$ Tax deductions and credits allow companies to subtract certain expenses (e.g. on training programmes, R\&D activities, capacity building of SMEs, and environmental protection) or revenues (e.g. export revenues) from taxable income and/or taxes.

${ }^{15} \mathrm{http}: / /$ oe.cd/gvc-mne

${ }^{16}$ Austria, Belgium, Bulgaria, Canada, Cyprus, Czech Republic, Germany, Denmark, Spain, Estonia, Finland, France, United Kingdom, Greece, Croatia, Hungary, Ireland, Italy, Japan, Lithuania, Luxembourg, Latvia, Netherlands, Norway, Poland, Portugal, Romania, Slovak Republic, Slovenia, Sweden, Turkey, United States.

${ }^{17}$ Austria, Belgium, Germany, Finland, France, United Kingdom, Hungary, Italy, Lithuania, Luxembourg, Latvia, Netherlands, Poland, Portugal, Sweden, United States. 


\section{References}

Andrenelli, A., C. Cadestin, K. De Backer, S. Miroudot, D. Rigo and M. Ye (2018), "Multinational production and trade in services", OECD Trade Policy Papers, No. 212, OECD Publishing, Paris, http://dx.doi.org/10.1787/16ec6b55-en.

Blomström, M. and A. Kokko (2003), "The Economics of Foreign Direct Investment Incentives", NBER Working Paper, No. 9489, Cambridge, MA, United States.

Cadestin, C., K. De Backer, I. Desnoyers-James, S. Miroudot, D. Rigo and M. Ye (2018a), "Multinational enterprises and global value chains: the OECD analytical AMNE database", OECD Trade Policy Papers, No. 211, OECD Publishing, Paris, http://dx.doi.org/10.1787/d9de288d-en.

Cadestin, C., K. De Backer, I. Desnoyers-James, S. Miroudot, D. Rigo and M. Ye (2018b), "Multinational enterprises and global value chains: New Insights on the trade-investment nexus", OECD Science, Technology and Industry Working Papers, No. 2018/05, OECD Publishing, Paris, http://dx.doi.org/10.1787/194ddb63-en.

Caves (1996), Multinational Enterprises and Economic Analysis, MIT Press, Cambridge, MA, United States.

De Backer, K., I. Desnoyers-James and L. Moussiegt (2015), "Manufacturing or Services - That is (not) the Question": The Role of Manufacturing and Services in OECD countries", OECD Science, Technology and Industry Policy Papers, No. 19, OECD Publishing, Paris, http://dx.doi.org/10.1787/5js64ks09dmn-en.

Greenstone, M. and E. Moretti (2003), "Bidding for Industrial Plants: Does Winning a "Million Dollar Plant' Increase Welfare?”, NBER Working Paper, No 9844, Cambridge, MA, United States.

Görg, H. and E. Strobl (2001), "Multinational Companies and Productivity Spillovers: A MetaAnalysis." Economic Journal, Vol. 111/475, pp. 723-739, http://dx.doi.org/10.1111/1468-0297.00669.

Havránek, T. and Iršová, Z. (2011), "Estimating vertical spillovers from FDI: why results vary and what the true effect is." Journal of International Economics, Vol. 85/2, pp. 234-244, http://dx.doi.org/10.1016/j.jinteco.2011.07.004.

Krugman, P. (1991), "Increasing Returns and Economic Geography”, Journal of Political Economy, Vol. 99/3, pp. 483-499.

Lipsey, R.E., and F. Sjöholm (2005), “The Impact of Inward FDI on Host Countries: Why Such Different Answers?", in T. Moran, E. Graham and M. Blomström (eds.), Does Foreign Direct Investment Promote Development?, Institute for International Economics and Center for Global Development, Washington, D.C., pp. 23-43.

Miller, R.E. (1966), “Interregional Feedbacks in Input-Output Models: Some Experimental Results”, Western Economic Journal, No. 7, pp. 41-50.

Miroudot, S. and C. Cadestin (2017), "Services in Global Value Chains: From Inputs to Value-Creating Activities", OECD Trade Policy Papers, No. 197, OECD Publishing, Paris, http://dx.doi.org/10.1787/465f0d8b-en.

OECD (2019), OECD Investment Policy Reviews: Southeast Asia, OECD Publishing, Paris

OECD (2011), Attractiveness for Innovation: Location Factors for International Investments, OECD Publishing, Paris http://dx.doi.org/10.1787/9789264104815-en. 
Paelinck, J., J. de Caevel and J. Degueldre (1965), “Analyse quantitative de certaines phénomènes du développement régional polarisé: Essai de simulation statique d'itinéraires de propagation", in Bibliothèque de l'Institut de Science Economique, Problèmes de conversion économique: Analyses théoriques et études appliquées, No. 7, M.-Th. Génin, Paris, pp. 341-387.

Smeets, R. (2008), "Collecting the Pieces of the FDI Knowledge Spillovers Puzzle”, World Bank Research Observer, Vol. 23/2, pp. 107-138.

Stone, S., J. Messent and D. Flaig (2015), "Emerging Policy Issues: Localisation Barriers to Trade", OECD Trade Policy Papers, No. 180, OECD Publishing, Paris, http://dx.doi.org/10.1787/5js1m6v5qd5j-en.

Timmer, M. P., Dietzenbacher, E., Los, B., Stehrer, R. and de Vries, G. J. (2015), “An Illustrated User Guide to the World Input-Output Database: the Case of Global Automotive Production", Review of International Economics, Vol. 23, pp. 575-605, https://doi.org/10.1111/roie.12178. 